\title{
Geomorphological applications of cosmogenic isotope analysis
}

\author{
Hermione A.P. Cockburna,b and \\ Michael A. Summerfield ${ }^{a, *}$
}

\author{
anstitute of Geography, University of Edinburgh, Drummond Street, Edinburgh \\ EH8 9XP, UK



\begin{abstract}
Cosmogenic isotope analysis involves the measurement of cosmogenic nuclides that have accumulated in the upper few metres of the Earth's surface as a result of interactions between cosmic rays and target elements. The concentrations of these cosmogenic nuclides can provide quantitative estimates of the timing and rate of geomorphic processes. In dating applications the concentration of cosmogenic nuclides is interpreted as reflecting the time elapsed since a surface exposure event. However, over most of the Earth's surface for most of the time the landsurface experiences incremental denudation and in these circumstances cosmogenic nuclide concentrations are related to the rate of denudation. Applications of event dating using cosmogenic isotopes include constructional landforms such as volcanic and depositional features, fault displacement, meteorite impacts, rapid mass movement, bedrock surfaces rapidly eroded by fluvial or wave action or exposed by glacial retreat, and the burial of sediment or ice. Strategies for quantifying rates of incremental change include estimates of denudation rates from site-specific samples and from fluvial sediment samples reflecting catchment-wide rates, and measurements of cosmogenic nuclide concentrations in soils and regolith to quantify rates of rock weathering. The past decade has seen a rapid growth in applications of cosmogenic isotope analysis to a wide range of geomorphological problems, and the technique is now playing a major role in dating and quantifying rates of landscape change over timescales of several thousands to several millions of years.
\end{abstract}

Key words: cosmogenic isotope analysis, cosmogenic nuclides, dating, denudation rates, geomorphology.

*Author for correspondence: Tel., 0131650 2519; fax, 0131650 2524; e-mail, mas@geo.ed.ac.uk 


\section{Introduction}

The Earth is under constant bombardment by cosmic radiation, primarily comprising protons, with a smaller proportion of $\alpha$-particles, electrons and heavier nuclei. A proportion of this cosmic radiation comes from the Sun, but the more energetic particles (typically $10^{8}-10^{10} \mathrm{eV}$ ) originate largely from our own galaxy, with the very highest energy particles (up to $10^{20} \mathrm{eV}$ ) having a source outside the Milky Way. It is the higher energy particles that are primarily responsible for generating the shower of secondary cosmic radiation in the upper atmosphere which reaches the Earth's surface. This secondary cosmic radiation flux, consisting predominantly of neutrons, with a much smaller component of muons, interacts with target elements in minerals in a shallow layer at the Earth's surface to produce, in situ, extremely small quantities of cosmogenic nuclides. Measurements of the amounts of these cosmogenic nuclides accumulated over time can provide valuable information on the age and rate of change of the land surface.

Until the development in the late 1970s and early 1980s of accelerator mass spectrometry (AMS) (Klein et al., 1982; Elmore and Phillips, 1987) and high-sensitivity noble gas mass spectrometry, cosmogenic isotope analysis was confined to the relatively much higher concentrations of cosmogenic nuclides found in meteorites and lunar samples that had received a cosmic-ray flux which had not been attenuated by the shielding effects of the Earth's atmosphere. Nonetheless, even prior to developing the capability to measure the exceedingly low concentrations of cosmogenic nuclides produced in situ in terrestrial materials, the potential for applying such measurements to geomorphological problems was recognized. In fact, the origins of using cosmogenic nuclides to determine the exposure history of the Earth's surface go back to Davis and Schaffer (1955) who used beta counting to date a late Quaternary surface on a chlorinerich phonolite. Other early contributions include a largely ignored paper published in German in the early 1970s (Fröhlich and Lübert, 1973) which proposed calculating denudation rates using in-situ-produced cosmogenic nuclides (see Tuniz et al., 1998), and the work by Srinivasan (1976) who measured cosmogenic ${ }^{126} \mathrm{Xe}$ to determine a 'surface residence time' for a sedimentary barite sample (see Cerling and Craig, 1994a).

Following the advances in measurement technology and the increased understanding of the in situ production of cosmogenic nuclides that was acquired during the 1980s, there has been a rapid growth in applications of cosmogenic isotope analysis in geomorphology and related fields of Quaternary science. From five or six papers per year in the early 1990s, the number has risen to 20 or more in the past two to three years (Figure 1). These totals are for applications papers only, and exclude a large body of theoretical and technical contributions.

The importance of cosmogenic isotope analysis as a technique in geomorphology arises, in part, from the timescale that it can address. Depending on the local rate of land surface stripping, cosmogenic isotope analysis can provide information on ages of geomorphic events, denudation rates and the operation of specific geomorphic processes over timescales ranging from thousands to millions of years. It thus forms a crucial bridge between investigations over the short term based on modern process rate measurements and historical data, and long-term studies based on techniques such as thermochronology (Burbank et al., 1996; Cockburn et al., 2000). A key advantage of a technique that provides information on denudation over these intermediate timescales 


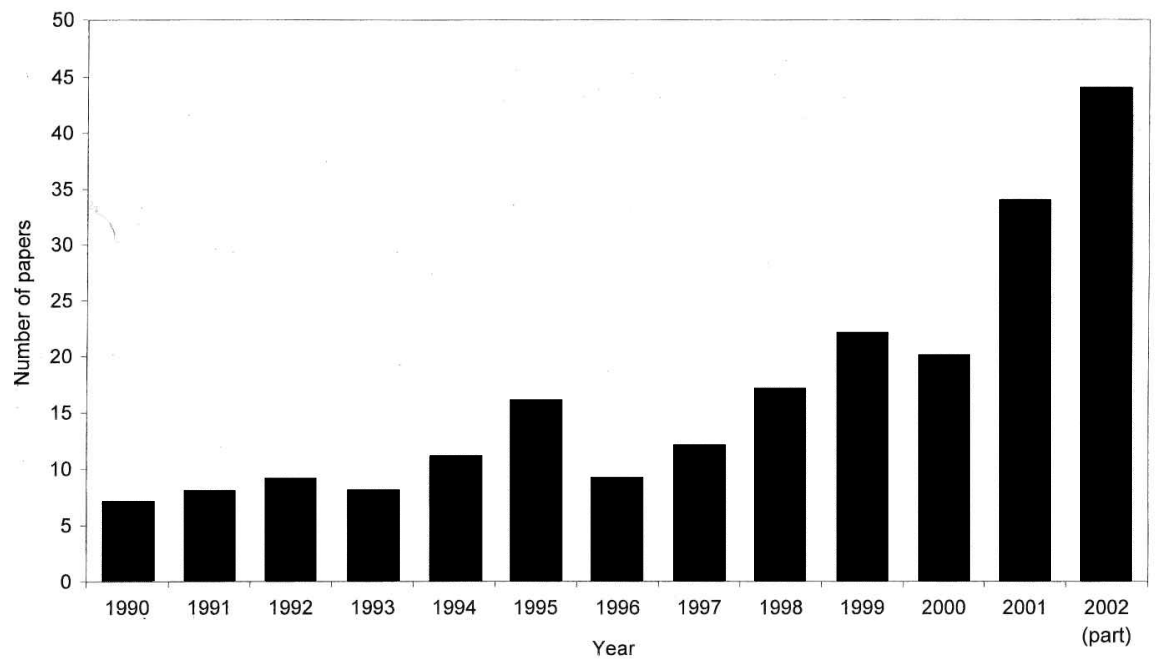

Figure 1 Growth in number of papers on geomorphological applications of in situ-produced cosmogenic nuclides published from 1990 to mid-2002

is that it can effectively average out short-term fluctuations in rates associated with climatic variations or other high frequency perturbations. It also circumvents, to a large extent, the problem of high magnitude-low frequency events which severely limit the potential to extrapolate short-term geomorphic process rate measurements (typically limited to a few years) to the longer term.

Another key advantage is the very wide scope for sampling in addressing a diverse range of geomorphological problems. Unlike information gleaned from geochronological techniques such as radiocarbon or luminescence dating, which are frequently confined to rather specific field situations, cosmogenic isotope data can be acquired from an enormous variety of geomorphologically useful contexts. This is the case because of the almost ubiquitous occurrence in common rock-forming minerals of the target elements for cosmogenic nuclide production (Table 1). The ability to date or quantify rates of landform change directly, rather than inferring chronological information about them indirectly, makes the technique particularly valuable. In short, cosmogenic isotope analysis enables geomorphological studies to be attempted that were previously impossible, it can address key questions about geomorphic process rates, and it provides the means to answer long-standing questions about landscape evolution.

In this review we focus on the geomorphological applications of in situ-produced cosmogenic isotope analysis, although many of the studies discussed, especially those involving the dating of landforms, also have great relevance to problems in Quaternary science. We exclude applications based on atmospheric (also known as 'meteoric' or 'garden variety') cosmogenic nuclide production, although this can also provide important insights into environmental processes (e.g., McKean et al., 1993; Stanford et al., 2000), not least in ${ }^{14} \mathrm{C}$ dating of organic materials. Our aim is to provide a comprehensive, although not exhaustive, survey to inform researchers unfamiliar with the technique of the potential of in situ-produced cosmogenic isotope analysis in advancing 


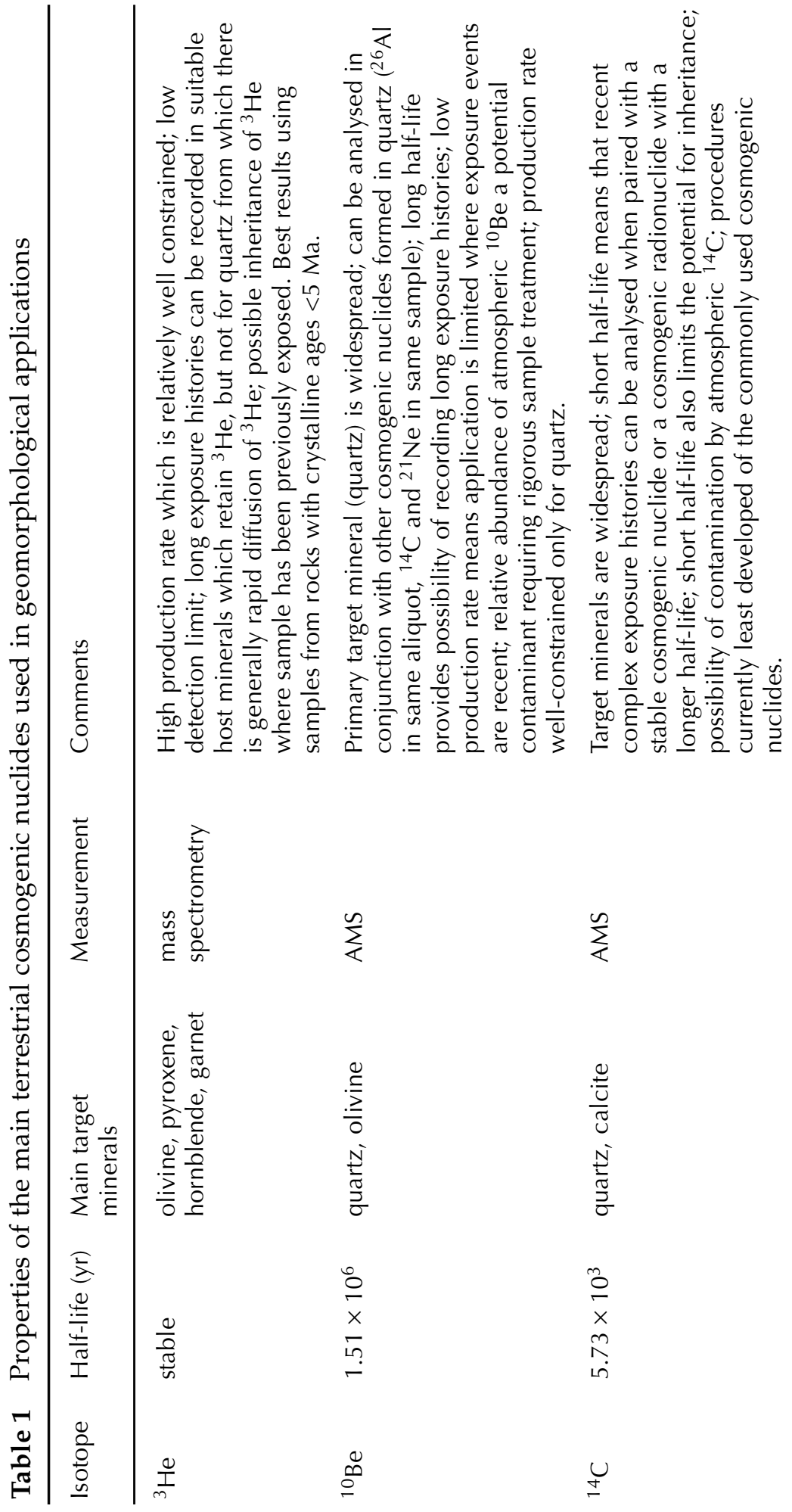






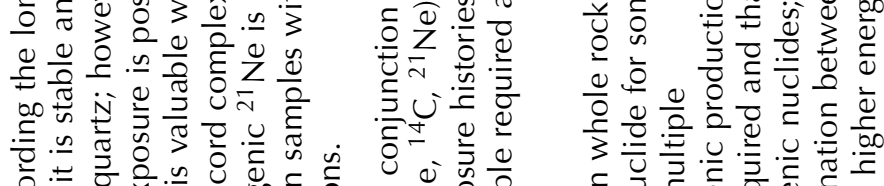

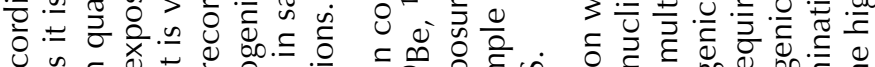

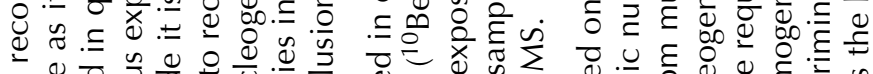

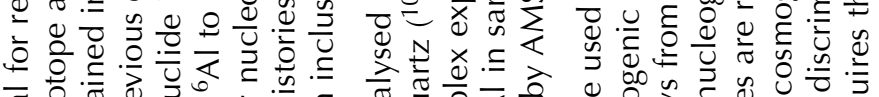
无. 屯.

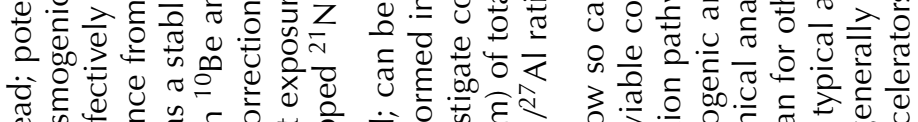



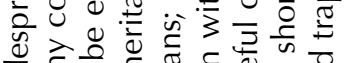

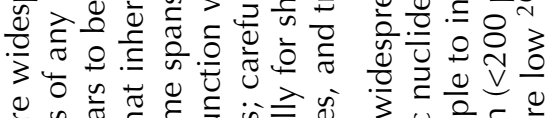

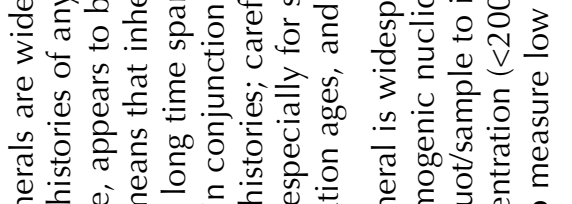


ह Do

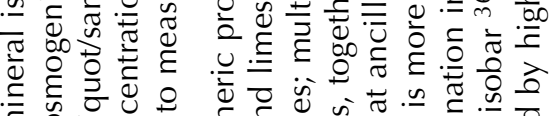
○一

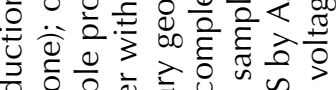

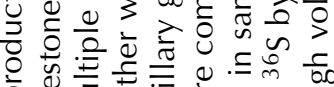

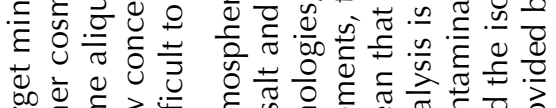

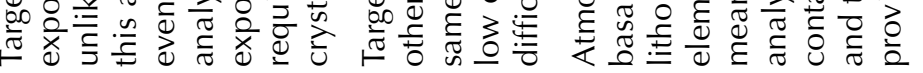

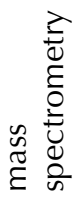

$\sum_{<}^{\infty}$

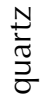





$\sum_{i}^{\infty}$

$\frac{\frac{1}{0}}{\frac{\pi}{n}}$

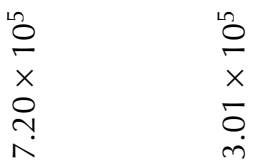

$\frac{0}{2}$

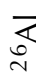

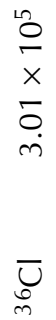


research in geomorphology and allied fields. Several excellent discussions of the principles and technical details of cosmogenic isotope analysis are already available, most notably the comprehensive review by Gosse and Phillips (2001), but also including contributions by Lal and Peters (1967), Lal (1988), Nishiizumi et al. (1993), Finkel and Suter (1993), Cerling and Craig (1994a), Bierman (1994), Kurz and Brook (1994), Tuniz et al. (1998), Fifield (1999) and Zreda and Phillips (2000). Discussions of cosmogenic isotope analysis are now also to be found in texts and reference manuals (e.g., Dickin, 1995; Noller et al., 2000), an indication that the technique is beginning to move from the purely development stage to more routine applications.

\section{Cosmogenic isotope analysis}

The main principles that govern the use of cosmogenic isotopes in geomorphology are conceptually simple: a cascade of cosmic radiation continuously bombards the Earth, of which a small proportion reaches the surface where nuclear interactions with terrestrial materials, such as soil or rock, produce cosmogenic nuclides. Strong attenuation of the cosmic-ray flux restricts production to the upper few metres of the Earth's crust; thus the concentration of in situ-produced cosmogenic nuclides in a surface sample provides a quantitative record of near-surface exposure. Lal (1988) identified 12 cosmogenic isotopes that are produced in terrestrial materials. Six of these have been significant in geomorphological investigations $-{ }^{3} \mathrm{He},{ }^{10} \mathrm{Be},{ }^{14} \mathrm{C},{ }^{21} \mathrm{Ne},{ }^{26} \mathrm{Al},{ }^{36} \mathrm{Cl}$ (Table 1) - whereas others, such as ${ }^{39} \mathrm{Ar}$ and ${ }^{41} \mathrm{Ca}$ (e.g., Loosli, 1983; Fink et al., 1990), will require further development for geomorphological applications.

Knowledge of production mechanisms and time-integrated production rates form the basis for the application of cosmogenic isotope analysis in geomorphology. Significant advances have been made since the pioneering work of Lal and Peters (1967), and reducing remaining uncertainties in production systematics remains a major research priority (Gosse et al., 1996; Dunai, 2000, 2001a, b, 2002; Stone, 2000, 2002; Desilets et al., 2001). Three principal mechanisms produce most cosmogenic nuclides: neutron spallation (the dominant process at the surface for all cosmogenic nuclides), thermal neutron capture and muonic interactions (which become of increasing relative importance with depth owing to the longer penetration lengths of these particles (Heisinger et al., 2002a, b) ). Production rates have been determined both empirically using natural and artificial targets (e.g., Nishiizumi et al., 1989, 1996; Cerling and Craig, 1994b; Niedermann et al., 1994; Kubik et al., 1998; Stone et al., 1998a; Dunai and Wijbrans, 2000) and theoretically (e.g., Lal, 1991; Masarik and Reedy, 1995; Masarik 2002; see also Gosse and Phillips, 2001: 1519). Production rates vary with location and time and must be scaled to account for a number of factors including depth within a target (Lal, 1991; Brown et al., 1992), altitude (atmospheric shielding) and latitude (primarily the spatial influence of the geomagnetic field) (Lal, 1991; Dunai, 2000; Stone, 2000), topographic shielding and sample surface slope (exposure geometry) (Dunne et al., 1999). Temporal influences that need to be addressed include variations in the cosmic-ray flux (Gosse and Phillips, 2001), several geomagnetic field parametres that vary with time (Kurz et al., 1990; Licciardi et al., 1999; Dunai, 2001b; Masarik et al., 2001), intermittent shielding by surface materials including regolith, sediments, snow and vegetation (Nishiizumi et al., 1989; Gosse et al., 1995a), loss of cosmogenic nuclides 
through diffusion from the host mineral (Trull et al., 1991; Brook et al., 1993), the effects of fire (Bierman and Gillespie, 1991; Zimmerman et al., 1994) and possible changes in the elevation of sampled sites (Lal, 1991; Brown et al., 1991). The net result of all these effects is that very careful sampling protocols are required based on a detailed understanding of the geomorphic processes operating at sampled sites (Gosse and Phillips, 2001) and quantitative modelling of production rates for each isotope and application (Lal, 1991; Dunai, 2000; Stone, 2000). Current levels of uncertainty are approximately $10-20 \%$, most of which results from production rate scaling for latitude and altitude (see Gosse and Phillips, 2001, for detailed discussion).

Cosmogenic nuclides accumulate in surface rocks as a function of production over time moderated by denudation and, for radioisotopes, radioactive decay. In some cases, relative concentrations in a suite of samples can be enough to solve a geomorphological problem. More often, translating measured abundances of cosmogenic nuclides into useful geomorphic data depends on the use of a suitable interpretative model based on an appreciation of probable site history. Various models have been devised, some being unique to individual applications. The simplest and most widely used model involves estimating the surface exposure age of a sample assuming that it has been suddenly exposed from a depth sufficient for it not to contain a pre-existing (inherited) cosmogenic nuclide component, and that it has not subsequently experienced denudation or burial. Under these circumstances a stable nuclide will continue to accumulate indefinitely and therefore have no theoretical upper age limit, although the zero denudation assumption is likely to be violated over longer timescales $\left(\sim>10^{5} \mathrm{yr}\right)$ and this imposes an upper limit to exposure dating. Radionuclides eventually attain an equilibrium concentration where production is balanced by radioactive decay. This point defines the theoretical upper age limit for cosmogenic radionuclide exposure dating, assuming zero denudation, and is reached after approximately four times the half-life of the radionuclide being used (Table 1). If the assumption of zero denudation is not met, or the nuclide concentration has become saturated, the model will yield an 'apparent' or minimum age. In cases where there has been progressive denudation rather than a sudden 'exposure event', the cosmogenic nuclide concentration can be used to estimate a rate of denudation assuming that the system is in secular equilibrium with respect to production, denudation, and decay (for radionuclides) (see Section V, 1). This model effectively quantifies the 'dwell time' of the upper 1-2 $\mathrm{m}$ of the surface. Such estimates are model-dependent since assumptions have to be made about secular equilibrium and the temporal variability in the denudation rate and are model maxima if these assumptions are not met (Bierman, 1994; Cerling and Craig 1994a).

\section{Range of applications}

In summarizing here the wide range of applications of cosmogenic isotope analysis to geomorphological phenomena, it is important to highlight the two ways of modelling cosmogenic nuclide concentrations by drawing a distinction between dating geomorphological 'events' and measuring incremental change. A geomorphological event in this context is a change in the landscape that, in relation to the background rate of modification of the landscape, represents an 'instantaneous' occurrence of sufficient magnitude to expose material that has previously been effectively shielded from cosmic 
radiation. Common examples would be exposure of a fresh bedrock face by a deep landslide, or by glacial retreat. Obviously once the 'event' has occurred 'normal' geomorphic processes can lead to progressive denudation of the 'event surface'. The depth of such modification, and therefore the effect on cosmogenic nuclide concentration, is likely to be negligible in most instances for young events (typically $\sim 1-3 \times$ $10^{4} \mathrm{yr}$ ) in comparison with the depth through which significant cosmogenic nuclide production occurs.

By incremental change we envisage the mode of landscape activity that occurs over most of the Earth's landscape for most of the time - that is, the progressive weathering and stripping away of material in increments that are small in comparison with the characteristic attenuation length (typically $\sim 0.6 \mathrm{~m}$ for rock) of cosmogenic nuclide production in Earth surface materials. Although there are important exceptions, it is usually more appropriate to regard the cosmogenic nuclide concentration of a sample as reflecting the net effect of cosmogenic nuclide production and the prevailing rate of denudation (and radioactive decay in the case of radionuclides), than to think of a land surface as having been initiated at a specific instance in the past and thereby seeing the landscape as comprising elements with specific 'ages'. We prefer the term 'denudation' to 'erosion' when referring to the overall removal of surface materials resulting from a combination of processes, or where the specific processes are undefined; we use 'erosion' where the process is predominantly or solely one of entrainment and transport of solid material by water, ice or wind. The distinction between dating events and recording rates of incremental change has been used as the basis for organizing this review (Table 2 ).

\section{Dating events}

\section{Constructional landforms}

a Volcanic landforms: The construction of new surfaces on volcanic landforms, which normally occurs 'instantaneously' in the context of long-term rates of landscape change, provides a clear example of a geomorphic event that can be dated through the accumulation of cosmogenic nuclides. Moreover, the ability to date volcanic rocks independently using radiometric techniques has provided an important means of determining cosmogenic nuclide production rates (Craig and Poreda, 1986; Kurz 1986a, 1986b, 1987; Phillips et al., 1986; Marti and Craig, 1987; Kurz et al., 1990; Nishiizumi et al., 1990; Poreda and Cerling, 1992; Laughlin et al., 1994). With these improved cosmogenic nuclide production rate data, surface exposure dating of lava flows is now able to provide independent corroboration of radiometric ages where post-eruptive denudation has been insignificant (Staudacher and Allègre, 1993), and has the potential to be used in preference to conventional radiometric methods in specific cases, especially for young flows and for samples with a low potassium content or inherited argon (Sarda et al., 1993; Zreda et al., 1993; Laughlin et al., 1994; Shepard et al., 1995).

Where there are reliable radiometric ages for lava flows, the difference in radiometric and apparent surface exposure age can be used to identify burial events and quantify the rate of post-eruptive denudation (Cerling, 1990). For instance, on Réunion Staudacher and Allègre (1993) found that the cosmogenic exposure age of $62 \pm 4$ ka for a lava flow was only slightly younger than its $65 \mathrm{ka} \mathrm{K}-\mathrm{Ar}$ age, thus constraining the rate 


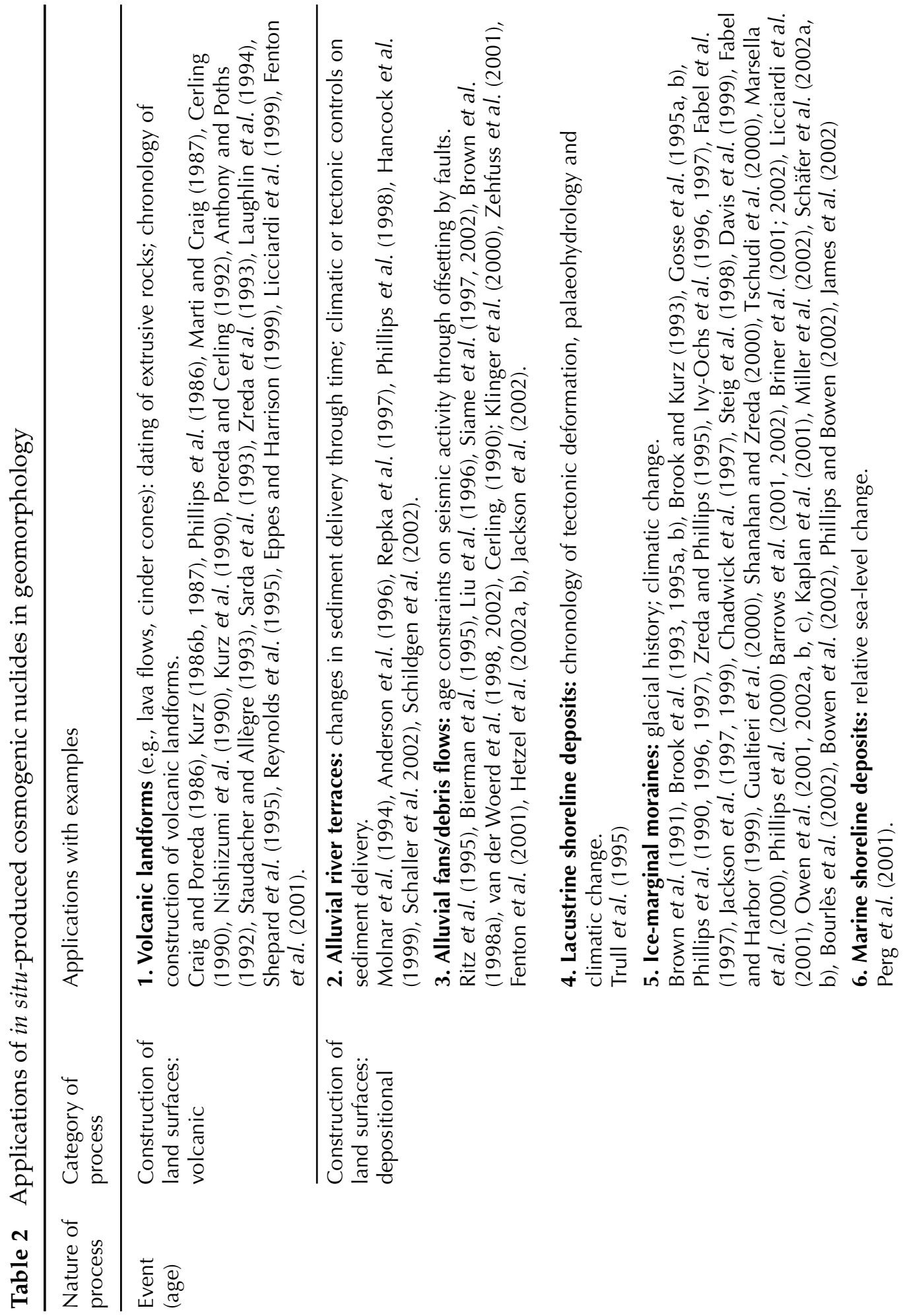




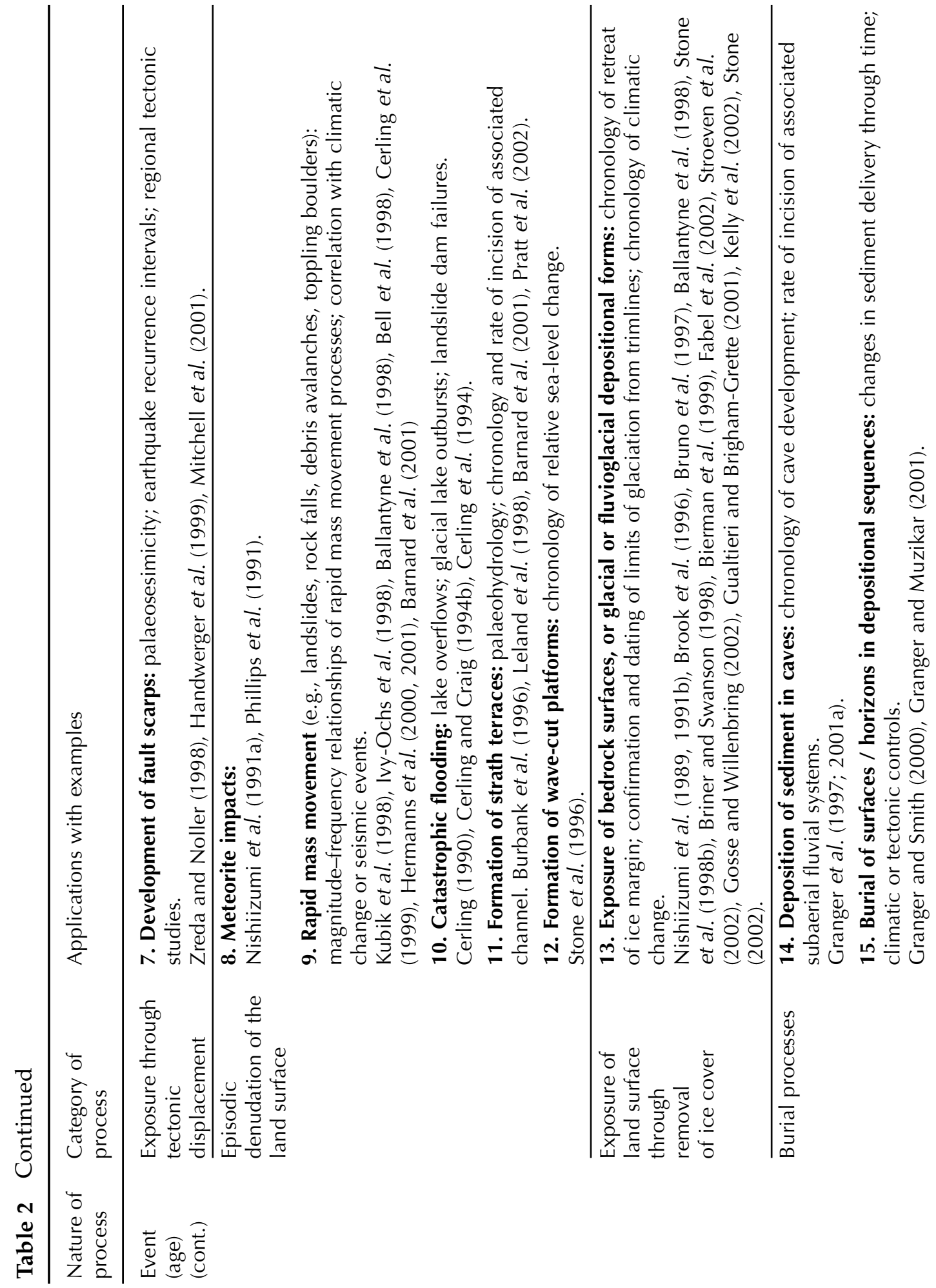




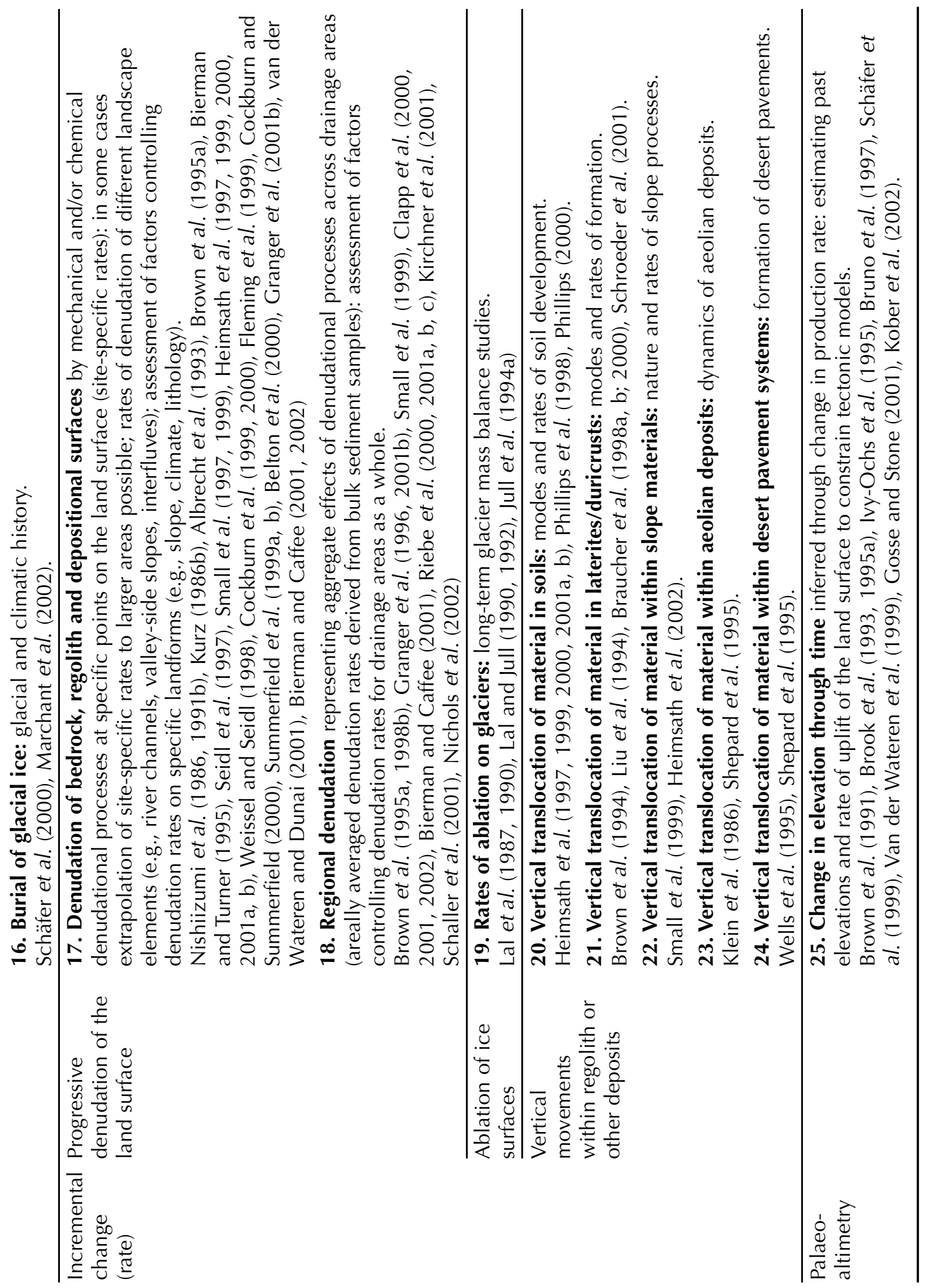


of denudation rate since eruption to less than $\sim 3 \mathrm{~m} \mathrm{Ma}^{-1}$, and confirming that the flow was not covered by scoriae or ash during subsequent eruptions. Other specific applications of cosmogenic isotope analysis to volcanic landforms have included using cosmogenic ${ }^{3} \mathrm{He}$ concentrations to investigate zonation and magma evolution of the Potrillo volcanic field, New Mexico, USA (Anthony and Poths, 1992; Eppes and Harrison, 1999), constraining surface flow stratigraphy and rates of eruption for Sierra Negra, the largest of the western Galapagos shield volcanoes (Reynolds et al., 1995), dating the displacement of volcanic features to constrain the age of caldera collapse on Réunion (Staudacher and Allègre, 1993), and quantifying rates of Quaternary fault movement in the Grand Canyon region, USA (Fenton et al., 2001; see Section IV, 2).

b Depositional landforms: Applications of cosmogenic isotope analysis to depositional landforms range from glacial moraines and erratics, to fluvial terraces, alluvial fans and debris flows, and lacustrine and marine shorelines. Compared with other methods for dating depositional landforms, such as conventional ${ }^{14} \mathrm{C}$ dating and luminescence techniques, the advent of in situ cosmogenic isotope methods has greatly expanded both the temporal range that can be addressed and the variety of sites that can be studied.

The dating of moraines and other glacial deposits through surface exposure ages has been a major application of cosmogenic isotope analysis, with most studies being focused on the chronology of the associated glacier fluctuations and their broader climatic and environmental implications, rather than with the dating of glacial landforms per se. Locations for such studies are worldwide, ranging from the British Isles (Bowen et al., 2002) to eastern Russia (Gualtieri et al., 2000), the western USA (Zreda and Phillips, 1995; Gosse et al., 1995a, b; Phillips et al., 1996, 1997, 1990; Chadwick et al., 1997; Licciardi et al., 2001; James et al., 2002), western Canada (Jackson et al.,1997, 1999), eastern Canada (Steig et al., 1998; Davis et al., 1999; Marsella et al., 2000; Kaplan et al., 2001; Miller et al., 2002), East Africa (Shanahan and Zreda, 2000), southeast Australia and Tasmania (Barrows et al., 2001, 2002), the Himalayas and Tibetan Plateau (Phillips et al., 2000; Owen et al., 2001, 2002a, b, c; Taylor and Mitchell, 2002; Schäfer et al., 2002a), and Antarctica (Brown et al., 1991; Brook and Kurz, 1993; Brook et al., 1993, 1995a, b; Fabel et al.,1997). A focal issue for a number of these and other studies of glacial deposits has been the chronology of glacial fluctuations marking the Late Glacial Maximum and the global synchrony, or otherwise, of the Younger Dryas (Ivy-Ochs et al., 1996, 1999; Tschudi et al., 2000; Briner et al., 2001, 2002; Phillips and Bowen, 2002; Bourlès et al., 2002; Schäfer et al., 2002b). However, in attempting to date the rapid climatic fluctuations represented by the last glacial to post-glacial transition, and in particular to identify any leads and lags in the climatic system between the northern and southern hemispheres, the current resolution of cosmogenic isotope analysis is being pushed to its limits, especially in view of uncertainties in cosmogenic nuclide production rates resulting from regional differences over time in the geomagnetic field and in mean atmospheric pressure (Stone, 2000; Gosse and Stone, 2001).

The simplest model for dating glacial moraines and similar glacial depositional forms assumes that blocks of bedrock with no prior exposure to cosmic radiation are either entrained at the glacier base, or fall on to the glacier surface and are rapidly incorporated as englacial debris. Subsequently these boulders are exposed at the surface when the ice cover is removed. Various factors, however, can produce more complex 
scenarios and these can result in a moraine of a particular age having constituent boulders with a range of cosmogenic surface exposure ages, and indeed moraines with identical cosmogenic exposure ages not being correlative (Hallet and Putkonen, 1994). One of these factors is inheritance, where individual boulders already contain a significant inventory of cosmogenic nuclides through exposure to cosmic radiation prior to incorporation as englacial or subglacial debris. Others are the differential weathering and erosion of boulders of contrasting lithologies, and the progressive exposure of boulders in a moraine through the removal of overlying finer material. Inheritance, which appears to characterize $10-20 \%$ of moraine boulders (Gosse and Phillips, 2001; Briner et al., 2001), produces exposure ages greater than the age of the moraine, whereas erosion gives rise to younger ages. The variation in exposure age as a result of erosion, which is obviously more significant on older moraines, has been modelled by Zreda et al. (1994), but a common strategy for dating a moraine is simply to discount individual boulders with exposure ages significantly younger or older (typically by several standard deviations) than the overall mean age (e.g., Zreda et al., 1999; Briner et al., 2002). In spite of these issues of data interpretation, the potential of cosmogenic isotope analysis to identify complex moraine sequences and to challenge previous chronologies of glacial landform development based on correlation through stratigraphic position is clear (Fabel and Harbor, 1999; Zreda and Phillips, 1995).

The question of inheritance is also prominent in applications of cosmogenic isotope analysis to other depositional landforms such as fluvial terraces (Molnar et al., 1994), alluvial surfaces (Liu et al., 1996) and shoreline deposits (Trull et al., 1995). In dating fluvial terraces in Wyoming and Utah, Anderson et al. (1996) addressed the problem by analysing two amalgamated samples of 30 clasts each, one from the surface and one from the subsurface at a depth sufficient for the sample to have been shielded from post-depositional cosmic-ray exposure. This enabled them to constrain cosmogenic nuclide accumulation prior to deposition. Developments of this approach involving multiple-sample depth profiles have been used to date suites of fluvial (Repka et al., 1997; Hancock et al., 1999) and marine (Perg et al., 2001) terraces, while Phillips et al. (1998) have modelled different vertical profile patterns of cosmogenic ${ }^{21} \mathrm{Ne}$ concentrations in stream terraces and alluvial fan deposits in New Mexico to assess the effects on exposure age of inheritance, changes in bulk density, erosion and burial. Where the age of a river terrace is independently known then the measured cosmogenic nuclide concentrations can be corrected for post-depositional production and the remaining cosmogenic nuclide inventory used to estimate the catchment-wide rate of denudation at the time of terrace formation (Schaller et al., 2002). More generally, cosmogenic surface exposure dating of fluvial terraces has significant potential for recording episodic incision and aggradation in fluvial systems over timescales of $10^{4}-10^{5} \mathrm{yr}$ (Schildgen et al., 2002) and thereby providing much needed chronological constraints on models of episodic erosion and complex response.

\section{Tectonic displacement}

A major application of cosmogenic isotope analysis has been the dating of fault movements to infer slip rates and earthquake recurrence intervals. The advantage of cosmogenic exposure dating here is that timescales typically up to $50 \mathrm{ka}$ can be 
addressed and seismic activity is therefore being monitored over geologically useful time spans. In the majority of studies surface exposure dating of displaced depositional features has been used to provide age constraints on fault movement. Offsets on alluvial fans have been used in central Asia (Ritz et al., 1995; Brown et al., 1998a; Hetzel et al., 2002a, b ), the southwest USA (Bierman et al., 1995; Fenton et al., 2001; Zehfuss et al., 2001), Argentina (Siame et al., 1997) and Jordan (Klinger et al., 2000), on piedmont alluvial surfaces in Argentina (Siame et al., 2002) and on fluvial terraces at several locations along the Kunlun fault in Tibet (Van der Woerd et al., 1998, 2002). In Otago, New Zealand, Jackson et al. (2002) have inferred the rate of propagation of an anticline above a blind reverse fault from the trend in cosmogenic ${ }^{10} \mathrm{Be}$ exposure ages of large silcrete boulders on the crest of the resulting uplifting ridge.

Fault displacement histories can also be inferred from cosmogenic nuclide inventories in bedrock fault scarps (Zreda and Noller, 1998). Measuring in situproduced ${ }^{14} \mathrm{C}$ in limestone, Handwerger et al. (1999) have estimated an age of $\sim 4600 \mathrm{yr}$ for the most recent movement of a fault in northern Utah, while Mitchell et al. (2001) have compared measured accumulations of cosmogenic ${ }^{36} \mathrm{Cl}$ concentrations on a limestone scarp face in northern Israel with modelled accumulations through time based on different fault displacement scenarios. In this latter study the best matches between modelled and measured ${ }^{36} \mathrm{Cl}$ concentrations indicated episodic behaviour of the fault and variations in mean displacement rate over the past $14 \mathrm{ka}$.

\section{Episodic denudation}

a Meteorite impacts: Perhaps the clearest example of an 'instantaneous' denudational event that exposes bedrock previously shielded from cosmic radiation is the creation of a crater by an impacting bolide. One of the most significant early applications of cosmogenic isotope analysis was the dating of the Meteor Crater impact site in Arizona, USA. Previous age estimates had ranged from $25 \pm 5 \mathrm{ka}$, based on stage of soil development, to $49 \pm 3 \mathrm{ka}$ from thermoluminescence data. Two independent studies employing ${ }^{36} \mathrm{Cl}$ (Phillips et al., 1991) and ${ }^{10} \mathrm{Be}$ and ${ }^{26} \mathrm{Al}$ (Nishiizumi et al., 1991a) confirmed the thermoluminescence dating, with Phillips et al. (1991) finding a mean age of $49.7 \pm 0.85 \mathrm{ka}$ for four ejected boulders, and Nishiizumi et al. (1991a) establishing an overall lower bound on the crater age of $49.2 \pm 1.7 \mathrm{ka}$. Cosmogenic isotope analysis is clearly applicable to dating recently formed terrestrial impact structures, and thereby improving estimates of impact recurrence intervals, although erosional, weathering and burial effects make sampling and data interpretation more complex for older craters.

b Rapid mass movement: An important issue in geomorphology is gaining an accurate assessment of the significance in landscape development of high magnitude-low frequency events. Rapid mass movement represents a suite of processes which are difficult to monitor directly because of their low frequency, although they may represent an important mode of hillslope transport in a number of geomorphic settings. Dating of these events through cosmogenic isotope analysis is not only yielding valuable insights into their role vis-à-vis other geomorphic processes, but also providing key quantitative data on slope failure processes and recurrence intervals, and for natural hazard assessment. 
Examining post-glacial landsliding on the Isle of Skye, Ballantyne et al. (1998) analysed cosmogenic ${ }^{36} \mathrm{Cl}$ in two blocks exposed during slope failure, but originating well below the original surface (in order to eliminate any inherited cosmogenic ${ }^{36} \mathrm{Cl}$ ). The measured surface exposure age of $6.5 \pm 0.5 \mathrm{ka}$ post-dates deglaciation by several thousand years and slope failure was therefore thought to be caused by joint extension and rock bridge shearing and/or seismic activity, rather than related to periglacial conditions. In attempting to relate rock failure events to seismic activity, Hermanns et al. $(2000,2001)$ have used cosmogenic ${ }^{21} \mathrm{Ne}$ to date eight superimposed rock avalanche deposits on the Puna Plateau in the central Andes, ranging in age from 152 to $31 \mathrm{ka}$, to investigate the influence of active faulting on slope oversteepening and subsequent gravitational collapse. In another study Bell et al. (1998) estimated the period elapsed since the last major seismic event at sites in California and Nevada by determining minimum- and maximum-limiting ages (using, respectively, rock-varnish microlaminations and cosmogenic ${ }^{36} \mathrm{Cl}$ ) of precariously balanced boulders that could be toppled by strong ground motion.

An important aspect of rapid mass movement events is their significance in environmental management. Through the relatively long timescales that it is able to address, cosmogenic isotope analysis can provide valuable benchmark data for comparison with historical or modern rates. For instance, in the Garwhal Himalaya, northern India, Barnard et al. (2001) have compared estimates of the enhancement of modern rates of landsliding and erosion caused by human activity (mostly through the removal of slope toes at road cuts) with longer-term rates of landsliding and river incision derived from cosmogenic ${ }^{10} \mathrm{Be}$ and ${ }^{26} \mathrm{Al}$ dating of strath terraces and two large (>10 million $\left.\mathrm{m}^{3}\right)$ mid-late Holocene slides. They concluded that in their study area anthropogenic influences are accelerating rates of denudation. Debris flows can play a significant role in modifying river channels through creating rapids or natural dams, and their frequency is important in the management of regulated rivers. Using a range of historical data and a variety of chronological techniques in association with cosmogenic ${ }^{3} \mathrm{He}$ exposure dating of olivine phenocrysts in basalt clasts, Cerling et al. (1999) have been able to estimate recurrence intervals for debris flows entering the Grand Canyon reach of the Colorado River at tributary junctions.

In addition to the application of cosmogenic surface exposure dating to rapid mass movement events of previously unknown age, independently dated events are potentially valuable sites for calibrating cosmogenic nuclide production rates since major landslides instantaneously expose rock previously buried below the depth of cosmic ray penetration. For example, the age of the Köfels landslide in Austria (9800 \pm $100 \mathrm{yr}$ dendro-calibrated relative to 1995 ) has been tightly constrained by ${ }^{14} \mathrm{C}$ dating of buried wood, and this has been used to determine the production rates of cosmogenic ${ }^{10} \mathrm{Be}$ and ${ }^{26} \mathrm{Al}$ (Ivy-Ochs et al., 1998; Kubik et al., 1998).

C Catastrophic flooding: As with major landslides, sites experiencing rapid erosion of bedrock or large boulders through deep scouring by catastrophic floods can be valuable for cosmogenic nuclide production rate studies when there is independent dating of flood events. For instance, erosion by the Bonneville flood in the Snake River Plain at the end of the last glacial ( 17.6 ka BP) has been used by Cerling (1990) and Cerling and Craig (1994b) to provide calibration sites for cosmogenic ${ }^{3} \mathrm{He}$ production. Cosmogenic surface exposure dating also has the potential to provide ages for 
previously undated catastrophic flooding events, as illustrated by the study of Cerling et al. (1994) who used cosmogenic ${ }^{3} \mathrm{He}$ and ${ }^{21} \mathrm{Ne}$ in basalt boulders and scoured bedrock to date the Big Lost River flood through Box Canyon in south-central Idaho. A range of ages amongst the samples was ascribed to inheritance of pre-flood cosmogenic nuclide production, but together the data indicated a maximum age of $\sim 20.5 \pm 1.9 \mathrm{ka}$ for the Big Lost River flood. This is essentially identical to the ${ }^{3} \mathrm{He}$ age of $20.5 \pm 0.8 \mathrm{ka}$ for the Owens River flood in California (Cerling, 1990; Cerling and Craig, 1994b). Both ages correlate with the beginning of the Missoula floods in the northwest USA and together they may indicate the start of glacial melting in the western USA (Cerling et al., 1994).

d Strath terraces: While catastrophic floods can scour bedrock to depths of many metres in a single event, lateral erosion of bedrock valley walls and progressive vertical incision of bedrock channels by 'normal' flood events can create flights of strath terraces whose height above the present channel and surface exposure age (time elapsed since abandonment) can together yield long-term mean rates of channel incision. Such incision rates are a key variable characterizing regional-scale rates of denudation and landscape change, especially in active orogenic settings. For instance, in the middle gorge of the Indus River near Nanga Parbat in the northwest Himalayas, cosmogenic ${ }^{10} \mathrm{Be}$ and ${ }^{26} \mathrm{Al}$ surface exposure ages of well-preserved strath terraces up to $410 \mathrm{~m}$ above the present channel indicate incision rates of 1-12 $\mathrm{m} \mathrm{ka}^{-1}$ with an acceleration of rates 15 ka ago (Burbank et al., 1996; Leland et al., 1998). To the southeast in the Garwhal Himalaya , Barnard et al. (2001) have inferred a fluvial incision rate of $4 \mathrm{~m} \mathrm{ka}^{-1}$ from two cosmogenically dated terraces above the Alaknanda River in their study focused on rates of landsliding. Strath terraces often exhibit patchy alluvial cover implying a complex history involving temporary burial after their initial formation. Careful field assessment prior to sampling is therefore necessary in order to assess the suitability of a simple surface exposure model (Molnar et al., 1994; Anderson et al., 1996). Where a simple exposure history does not apply surface exposure ages of flights of strath terraces cannot be used directly to estimate channel incision rates, but may yield other useful information. For instance, Pratt et al. (2002) found similar surface cosmogenic $\left({ }^{10} \mathrm{Be}\right.$ and $\left.{ }^{26} \mathrm{Al}\right)$ exposure ages of around $7 \mathrm{ka} \mathrm{BP}$ for fluvially eroded surfaces in central Nepal across a height range of 43-124 m above the channel of the Marsyandi River and interpreted this to be the result of filling of the valley by sediment at least $80 \mathrm{~m}$ thick during a period of more active landsliding triggered by enhanced early Holocene monsoonal precipitation.

e Wave-cut platforms: Analogous to the cutting of new surfaces into bedrock by fluvial channel incision is the formation of wave-cut platforms through the erosive effects of wave action on shoreline bedrock outcrops. The exposure histories (formation ages) of these landforms are important both in tracking relative sea-level change, and, where the global sea-level change is independently constrained, quantifying rates of active tectonic, or glacio-isostatic, surface uplift. Although radiocarbon dating and other radiometric techniques have been widely employed, notably to raised coral reefs, cosmogenic isotope analysis is valuable where the bedrock, or associated deposits, are not suitable for these other dating methods. Stone et al. (1996) have presented data for the 'Main Rock Platform' in western Scotland with cosmogenic ${ }^{36} \mathrm{Cl}$ apparent ages or 'effective irradiation times' based on a simple exposure model. They note, however, that 
this will not represent the true age if marine transgressions or other temporary shielding effects are not taken into account. Nonetheless, even with these uncertainties, their study demonstrates that apparent ages alone place the formation of the Main Rock Platform firmly in the termination phase of the last glacial.

\section{Removal of ice cover}

Conceptually, one of the simplest applications of cosmogenic isotope analysis is dating the removal of an ice cover from bedrock surfaces, moraines or glacial erratics. It is not surprising therefore, that much emphasis was placed on this kind of study in the initial applications of cosmogenic surface exposure dating. For instance, Nishiizumi et al. (1989) used glacially polished rocks exposed by the (radiocarbon-dated) retreat of Tioga stage glaciers in the Sierra Nevada to calibrate ${ }^{10} \mathrm{Be}$ and ${ }^{26} \mathrm{Al}$ production rates (see also Clark et al., 1995). Cosmogenic isotope exposure dating of glacial retreat across bedrock surfaces has subsequently been applied in Antarctica (Nishiizumi et al., 1991b), eastern Canada and the Arctic (Bierman et al., 1999; Gualtieri and Brigham-Grette, 2001) and the Swiss Alps (Kelly et al., 2002). Many studies of the chronology of glacial retreat have combined data on bedrock forms with the exposure of glacial depositional landforms, the assumption being that careful sampling from features such as moraines and erratics can also provide reliable constraints on the timing of glacial retreat (e.g., Ivy-Ochs et al., 1997; Steig et al., 1998; Schäfer et al., 1999; Zreda et al., 1999; Marsella et al., 2000; Kaplan et al., 2001; Karhu et al., 2001; Owen et al., 2001, 2002b; Bourlès et al., 2002; Bowen et al., 2002; Oberholzer et al., 2002; James et al., 2002; Stone et al., 2002) (see Section IV, 1 b).

An exposure age for the removal of ice cover through glacial retreat or wasting will only be valid if the thickness of shielding ice (several multiples of the attenuation length for ice) has been sufficient to effectively shut down cosmogenic nuclide production. Moreover, the depth of scouring by glacial erosion prior to a glacial retreat episode has to be great enough to remove the vertical zone of bedrock in which cosmogenic nuclides produced during any earlier exposure episode would be residing. If this were not the case, the cosmogenic nuclide concentration measured would include an inherited component. In some studies, such as that for Tumbling Glacier, Baffin Island (Davis et al., 1999), samples collected just beyond an actively retreating ice front have indeed been found to contain minimal cosmogenic nuclide concentrations. But instances where this is not the case can provide valuable insights into the effectiveness of glacial erosion during individual episodes of glacial advance. For example, assuming that any inherited cosmogenic nuclide component related only to the most recent interglacial, Briner and Swanson (1998) calculated an erosion rate of $0.09-0.35 \mathrm{~mm} \mathrm{yr}^{-1}$ for the Cordilleran Ice Sheet at Mt Erie in the Puget Sound region of Washington State, USA from excessive cosmogenic ${ }^{36} \mathrm{Cl}$ concentrations compared with the well-constrained radiocarbon deglaciation age. In studying the possible preservation of preglacial topography in areas subject to frozen bed conditions under the Fennoscandian Ice Sheet in Sweden, Fabel et al. (2002) and Stroeven et al. (2002) have found that cosmogenic nuclide concentrations in erratic boulders gave consistent deglaciation ages, thus confirming ice sheet overriding as opposed to ice-free conditions, but concentrations of ${ }^{10} \mathrm{Be}$ and ${ }^{26} \mathrm{Al}$ in preserved tors within the landscape suggested minimal erosion over several glacial cycles. Similarly, Bierman et al. (1999) and Gosse and Willenbring (2002) 
have found complex exposure histories and evidence of inheritance indicating differential erosion under the Laurentide Ice Sheet.

The vertical extent of former glaciers and ice sheets is an important variable required for determining past ice volumes and for palaeoclimatic reconstructions. Geomorphic indicators of previous ice levels range from clearly defined trim lines to more equivocal weathering limits which may reflect other zones of process transition, such as postglacial differential weathering or englacial boundaries between wet-based eroding ice and noneroding frozen-bed ice. Cosmogenic exposure dating of bedrock surfaces across these transition zones can help to distinguish between different processes of formation, as well as providing information on the chronology of changes in ice volume (Brook et al., 1996; Stone et al., 1998b).

\section{Burial events}

a Sediment burial: In addition to the chronological information that can be derived from cosmogenic nuclide concentrations in deposits formed on the land surface, valuable information can also be garnered in circumstances where sediments previously exposed to cosmic radiation are rapidly buried beyond the zone of cosmogenic nuclide production. This is because the differential decay of cosmogenic nuclides with different half-lives will indicate the time elapsed since burial, and hence the date of deposition. A particularly useful situation in which such rapid sediment burial occurs is in caves, and in the first use of this application Granger et al. (1997) measured cosmogenic ${ }^{10} \mathrm{Be}$ and ${ }^{26} \mathrm{Al}$ concentrations to date burial times of alluvium deposited in abandoned caves above the present level of the New River, Virginia, USA, and to constrain the rate of downcutting of the river during the Quaternary. Granger et al. (2001a) also constrained the evolution of Mammoth Cave in Kentucky by dating a series of sediments deposited by the Green River. They were able to show that the river's incision history was in step with major climatic changes and drainage reorganizations associated with fluctuations in the margin of the Laurentide Ice Sheet.

The cosmogenic nuclide inventories in sediments buried within depositional forms such as river terraces can also provide valuable chronological information. For example, although determining the cosmogenic nuclide concentration of surface samples can yield valid ages for well-preserved river terraces (see Section IV, $1, b$ ), this strategy cannot be applied to older, degraded terraces which may have experienced several metres of erosion. In such cases, however, the differential decay of two radioactive cosmogenic isotopes (commonly ${ }^{26} \mathrm{Al}$ and ${ }^{10} \mathrm{Be}$ ) collected from depth can be used to estimate the age of terrace formation assuming that post-burial cosmogenic nuclide production is known (Granger and Smith, 2000). Such production can continue at a depth of several metres because of the deep penetration of fast muons (Granger and Smith, 2000; Granger and Muzikar, 2001).

b Burial of glacial ice: An unusual, but key, application of cosmogenic isotope data to constrain the chronology of a burial event is provided by the controversy over the age of a subsurface body of glacial ice in Beacon Valley, Southern Victoria Land, Antarctica. The significance of this buried ice is that if it is of Miocene age (minimum 8.1 Ma BP) - as has been inferred from stratigraphic relationships to overlying tills 
dated by ${ }^{40} \mathrm{Ar} /{ }^{39} \mathrm{Ar}$ analyses of presumed in situ volcanic ash - it confirms the persistence of a cold, hyper-arid climate in the area throughout the Pliocene and refutes the notion of an unstable East Antarctic Ice Sheet during this period (Sugden et al., 1995). The ability of ice in the near subsurface to survive sublimation over the time spans proposed has been questioned (Hindmarsh et al., 1998), as has the interpretation that the volcanic ash deposits are undisturbed and thus provide a chronological constraint on the age of the ice. Through an analysis of the concentrations of cosmogenic ${ }^{3} \mathrm{He}$ and ${ }^{21} \mathrm{Ne}$ in two surface dolerite erratics and one shielded erratic from within the ice, Schäfer et al. (2000) demonstrated that sublimation rates could not have exceed more than a few metres per million years and that the ice must be at least several million years old. Marchant et al. (2002) have addressed the question of whether the volcanic ash is in situ, especially in view of the presence of well-developed polygonal patterned ground developed in the till. Two profiles of cosmogenic ${ }^{3} \mathrm{He}$ concentrations through the till deposit show it to have formed through sublimation of the underlying ice and indicate the long-term stability of the till layer in areas unmodified by pattern ground formation.

\section{Incremental change}

1 Site-specific denudation rates

As pointed out in Section III, most of the Earth's surface is subject to the incremental change associated with bedrock weathering, hillslope processes, and sediment and solute transport, rather than discrete geomorphic events involving the instantaneous exposure of rock through the removal of several metres of overburden. Consequently, rather than thinking of an 'event exposure age', in most cases it is more meaningful to interpret concentrations of cosmogenic nuclides as reflecting these rates of incremental denudation.

The key to quantifying denudation rates using surface concentrations of cosmogenic nuclides is changes in production with depth, since denudation involves bringing up to the surface rock that was previously buried. In a steadily eroding rock outcrop, the cosmogenic nuclide concentration approaches saturation, or secular equilibrium, as a result of constant production on the one hand and losses by denudation as well as radioactive decay (in the case of radionuclides) on the other. After initial exposure secular equilibrium will be reached when sufficient time has elapsed for denudation to remove a depth of rock two or three times the attenuation length (see Section III), assuming denudation has been occurring in small increments relative to the attenuation length. Under these circumstances a measured surface concentration can be accurately modelled in terms of a constant denudation rate representing an integrated rate for the minimum period of time required to reach secular equilibrium (Nishiizumi et al., 1986; Kurz, 1986b; Lal, 1991). This model is commonly referred to as the 'steady-state erosion model', with the term 'steady-state' often used to refer to both secular equilibrium and the particular style of denudation required to satisfy the model. If the system has not yet reached saturation, then the model will overestimate the denudation rate, whereas if erosion is occurring episodically (i.e. in increments that are large relative to the attenuation length), or the exposure history is complex and has included periods of burial, then the model may either overestimate or underestimate the true rate (Lal, 1991; 
Small et al., 1997). In favourable circumstances, the ratio of two radionuclides with different half-lives can be used to test the assumptions of the steady-state erosion model. The ratios of ${ }^{10} \mathrm{Be}$ and ${ }^{26} \mathrm{Al}$ are commonly used in such cases to test for complex exposure histories involving burial episodes and/or episodic or highly temporally variable denudation rates, with the behaviour associated with particular isotope ratios being depicted on an erosion-island graph (Klein et al., 1986; Lal, 1991). Measurement uncertainties mean that the test for episodic denudation may be inconclusive, progressively more so for denudation rates $>1 \mathrm{~m} \mathrm{Ma}^{-1}$ (Small et al., 1997). Nonetheless, even though errors resulting from an inappropriate application of the steady-state erosion model can be greater than both measurement and production rate errors, a more accurate denudation rate estimate can be obtained by calculating the mean from many individual steady-state erosion rate measurements (Small et al., 1997).

Site-specific denudation rates based on the steady-state erosion model have been estimated for a wide range of locations and geomorphic settings (Table 3). These rates are naturally biased towards low values because of preferential sampling of bare bedrock surfaces that are usually the most slowly eroding and resistant components of the local landscape. Variations in rates can also be evident depending on microtopography and other detailed characteristics of the specific sampling site selected. Extrapolation of these rates across the landscape can, therefore, be problematic, and uncertainties can arise from the difficulties in strictly fulfilling the assumptions of the steady-state erosion model. Notwithstanding these caveats, the studies listed in Table 3 represent a major advance in quantifying rates of denudation integrated over geomorphologically useful periods of time $\left(10^{3}-10^{6}\right.$ years $)$ compared with the previous paucity of data relevant to these timescales. That uncertainties over the appropriate erosion model in any particular case, together with analytical and production rate errors, may produce total errors in denudation rate estimates in some cases exceeding $50 \%$ must be placed in the context of the lack of data for similar timescales provided by other techniques. Whilst such large errors would be unacceptable in cosmogenic surface exposure studies attempting, for instance, to resolve uncertainties in the timing of late glacial events, they may not be problematic in studies where establishing approximate rates of denudation is sufficient to test often long-standing notions about rates and modes of landscape change. For example, cosmogenic-nuclide based estimates of escarpment retreat rates of $10-100 \mathrm{~m} \mathrm{Ma}^{-1}$ over the past $10^{4}-10^{6} \mathrm{yr}$ for the Great Escarpment in southern Africa contrast with a mean rate of retreat of the order of 1000 $\mathrm{m} \mathrm{Ma}^{-1}$ implied by King's classic model of landscape evolution for the area (Fleming et al., 1999; Cockburn et al., 2000). Similarly, although cosmogenic nuclide concentrations have demonstrated some exceedingly slow rates of denudation of $\sim 5 \mathrm{~m} \mathrm{Ma}^{-1}$ or less for erosion surfaces and inselbergs in Australia, southern Africa and Antarctica (Nishiizumi et al., 1991b; Bierman and Turner, 1995; Cockburn et al., 1999; Cockburn and Summerfield, 2000; Summerfield et al., 1999a, b ; Belton et al., 2000; Bierman and Caffee, 2001), these rates would still be too high to preserve intact erosion surfaces over the time intervals of up to $50 \mathrm{Ma}$ or more that have been proposed.

\section{Catchment-averaged denudation rates}

An obvious potential limitation of site-specific sampling in providing data relevant to denudation rates at a broader scale is the 'nonrandom' nature of sample selection. 
Where sampling is from bedrock outcrops in terrain that is predominantly blanketed by regolith, denudation rates are likely to be less than the regional average since exposed bedrock is likely to be present because it is eroding less rapidly than its surroundings. In principle, however, the process of denudation, from the weathering of bedrock to the transport of material on slopes and the transmission of sediment in river channels, provides a natural sampling mechanism whereby each of many thousands of individual mineral grains in a river sediment sample will carry its own history of exposure to cosmic radiation. By averaging together these individual exposure histories through the analysis of a single sample of sediment from a river channel it is possible to estimate the mean rate of denudation for the catchment area upstream of the sampling site. This principle was first suggested by Lal and Arnold (1985), and was tested by Brown et al. (1995a) in the Icacos basin in Puerto Rico, where a denudation rate of $\sim 43 \mathrm{~m} \mathrm{Ma}^{-1}$ was estimated. This study, together with that of Granger et al. (1996), identified a range of factors that have to be addressed in making such denudation rate estimates; these include variations in production rates throughout the basin (especially as a function of elevation), variations in bedrock mineralogy, the storage and remobilization of sediment, differential weathering of different calibre grains, regolith mixing through bioturbation, physical weathering and slope processes, and the mixing of sediment from areas of different erosion rates. In evaluating the method, Granger et al. (1996) compared denudation rates estimated from cosmogenic nuclide concentrations in present-day river sediment with rates derived from sediment volumes in well-dated alluvial fans in two small catchments in northeast California. The close correspondence between the two sets of estimates confirmed that in small catchments with little sediment storage cosmogenic nuclide concentrations in river sediment can provide a good estimate of basin-wide long-term denudation rates. In a general assessment of the viability of this basin-averaged approach to cosmogenic isotope analysis, Bierman and Steig (1996) concluded that it provides an effective means of estimating denudation rates in basins in isotopic steady state and where the sampled sediments are well mixed. However, care has to be taken where quartz grains are being analysed (as is frequently the case for cosmogenic ${ }^{10} \mathrm{Be}$ and ${ }^{26} \mathrm{Al}$ ) since the relative resistance of quartz to dissolution means that its residence time in regolith will be longer than the average for all mineral grains (Small et al., 1999), although the resulting bias is probably modest compared with the other uncertainties in cosmogenic denudation rate estimates (Riebe et al., 2001a).

The ability to use cosmogenic nuclide concentrations to characterize basin-wide as well as site-specific denudation rates has provided the opportunity to compare areally averaged denudation rates with those for specific landform elements and subcatchments within basins. For instance, Granger et al. (2001b) showed that in the Diamond Mountains batholith in California, exposed granite bedrock has been eroding more slowly than the average rate for catchments in which they are found. Similarly, Bierman and Caffee (2001) found that denudation rates for bedrock samples in Namib Desert were lower than catchment-averaged rates from channel sediment samples. In the Yuma Wash basin in southwest Arizona, Clapp et al. (2002) used channel sediment samples to compare sediment generation rates for subcatchments as well as the basin as a whole. They found that in the upland subcatchments cosmogenic nuclide concentrations reflect rates of sediment generation from bedrock weathering, whereas sediment in the main channel also includes the long-term effects of sediment storage 


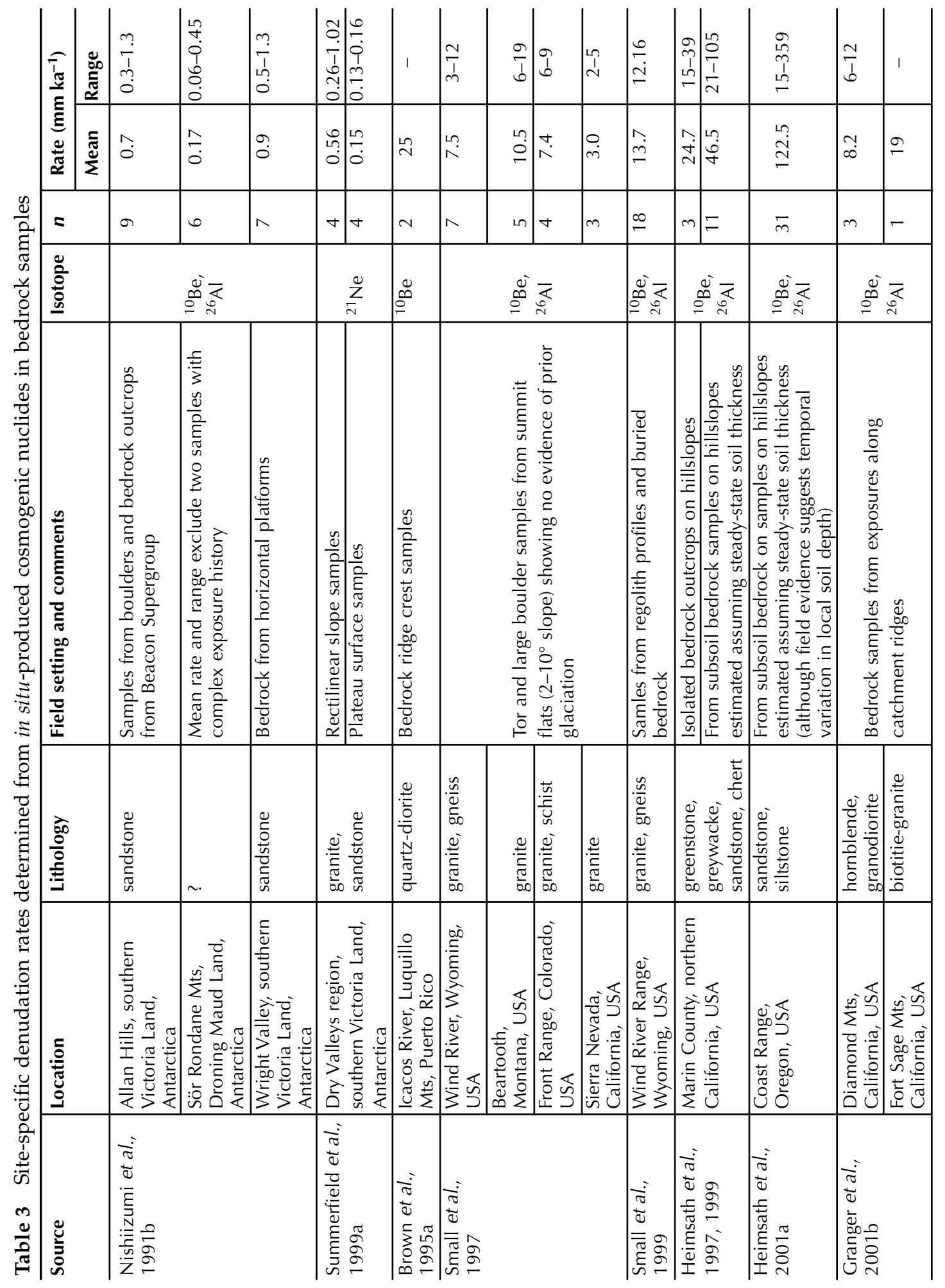







and reworking. Further west in the Mojave Desert Nichols et al. (2002) have measured cosmogenic ${ }^{10} \mathrm{Be}$ and ${ }^{26} \mathrm{Al}$ in sediment samples to document rates and processes of piedmont modification.

As well as exploring the spatial variability of denudation rates, catchment-averaged rates derived from cosmogenic nuclide concentrations (which reflect denudation over periods of $10^{3}-10^{6}$ years) can usefully be compared with rates derived from modern measurements of river sediment yield. For instance, Brown et al. (1998b) used cosmogenic ${ }^{10} \mathrm{Be}$ in fluvial sediments to assess differences between modern and predevelopment rates of denudation in Puerto Rico, and found evidence for a significant anthropogenic enhancement of modern sediment discharges. In the Negev Desert, Israel, Clapp et al. (2000) compared the 33-yr sediment budget of a small, intensively studied basin with cosmogenic ${ }^{10} \mathrm{Be}$ and ${ }^{26} \mathrm{Al}$ estimates of the longer-term sediment flux and found that the modern rates of sediment transport exceed the longer-term average by $53-86 \%$, thus indicating current evacuation of sediment accumulated during previous periods of enhanced sediment generation. By contrast, in the more humid setting of western Europe, Schaller et al. (2001) found catchment-averaged denudation rates from cosmogenic ${ }^{10} \mathrm{Be}$ in quartz for catchments in the Allier, Meuse, Neckar and Regen basins to be 1.5-4 times greater than those derived from modern river loads. They suggest that this may be due to under-representation in the modern record of high magnitude-low frequency events, to inheritance of an elevated Pleistocene signal or to nonuniform erosion and preferential sourcing of modern sediment from the deeper (and therefore less cosmogenically exposed) zones of the subsurface. A similar relationship between modern and longer-term rates was found by Kirchner et al. (2001) in their assessment of erosion rates over a range of timescales in mountainous granitic catchments in Idaho, USA. Here they estimated that mean rates over the past $\sim 10 \mathrm{ka}$ derived from cosmogenic ${ }^{10} \mathrm{Be}$ concentrations in river sediment are on average 17 times greater than modern stream fluxes, a difference that they interpret as arising from the underestimation of rare but catastrophic erosional events in short-term stream-load monitoring. Clearly even these few studies both caution against simple generalizations about anthropogenic enhancements of modern sediment discharges and question the reliability of short-term records of river sediment load as indicators of longer-term process rates.

The growing application of catchment-averaged denudation rates from cosmogenic nuclide concentrations has gone beyond the simple documentation of rates and comparison of different timescales to the testing of assumptions about the efficacy of factors controlling denudation and landscape development. For example, measurements of cosmogenic ${ }^{10} \mathrm{Be}$ and ${ }^{26} \mathrm{Al}$ in stream sediments in the Sierra Nevada have demonstrated a strong augmentation of denudation rates in the proximity of fault scarps (Riebe et al., 2000), but a lack of correlation with climate (Riebe et al., 2001b). Moreover, by combining estimates of long-term rates of mechanical denudation from cosmogenic nuclide concentrations in sediment with estimates of solute loss from the enrichment of insoluble elements in regolith, Riebe et al. (2001c) have shown a strong correlation between rates of mechanical and chemical denudation, but a lack of correlation between chemical denudation rates and climate. 


\section{Accumulation and ablation of ice surfaces}

A specific application of cosmogenic isotope analysis of relevance to glacial geomorphology involves the use of ${ }^{10} \mathrm{Be}$ and ${ }^{14} \mathrm{C}$ produced in situ in ice by neutron spallation of oxygen nuclei as recorders of glacier accumulation and ablation rates (Lal et al., 1987; Lal and Jull, 1990; Jull et al., 1994a). This is analogous to the use of cosmogenic isotopes to record sediment deposition and denudation, except that it is the accumulation or loss of ice that is being recorded by cosmogenic nuclide concentrations. However, differentiating the in situ component from atmospheric cosmogenic nuclides trapped in air during the firn-ice transition and those deposited by wet precipitation is complex. This is particularly so for ${ }^{10} \mathrm{Be}$ since atmospheric sources exceed the in situ component by an order of magnitude and this kind of application is therefore limited to special cases (Lal and Jull, 1992). For instance, using ${ }^{14} \mathrm{C}$ Lal et al. (1990) estimated ice ablation rates of 58 \pm 7 and $76 \pm 8 \mathrm{~mm} \mathrm{yr}^{-1}$ for two locations in the Allan Hills main ice field, Antarctica, these rates being in agreement with those determined using stakes. Similarly, the ${ }^{14} \mathrm{C}-$ based estimates by Lal et al. (1987) of accumulation rates for the Greenland Ice Sheet were also found to be in line with recent model estimates.

\section{Regolith and soil development}

The depth-dependence of cosmogenic nuclide production rates provides a valuable means of quantitatively monitoring those processes in soil and regolith in which there is a vertical component to the movement of material relative to the surface. Using this approach, data from cosmogenic isotope analysis have started to provide the means to evaluate models of soil and regolith development that were previously untestable with reference to the usually lengthy timescales over which the relevant processes operate. An elegant example is provided by the testing by Wells et al. (1995) of a model of stone (desert) pavement formation. In contrast to the idea of stone pavements resulting from a progressive concentration of gravel at the surface as a result of the swelling and shrinkage of surrounding fines, or through the removal of fines through deflation or sheet wash, the similarity of surface exposure ages derived from cosmogenic ${ }^{3} \mathrm{He}$ concentrations in their pavement gravel and adjacent bedrock samples demonstrated continuous exposure of both components. As also shown in a similar study by Shepard et al. (1995), these data are inconsistent with the gradual emergence of individual gravel clasts over an extended period of time (the 'lag' hypothesis), but accord with a model of stone pavement formation involving vertical inflation through the infiltration of fines from above.

The very extended time periods over which duricrusts, lateritic weathering profiles and associated weathering materials typically develop mean that the processes that form them cannot be adequately encompassed by short-term measurements or monitoring. Cosmogenic nuclides, however, provide a powerful means of investigating the long-term development of such weathering forms through their ability to record progressive burial or exposure of components of weathering profiles. For instance, Brown et al. (1994) used ${ }^{10} \mathrm{Be}$ and ${ }^{26} \mathrm{Al}$ measurements in quartz veins and pebbles in West African lateritic crusts both to determine erosion rates for the weathering profile surfaces and to distinguish between profiles that are being eroded from those that are experiencing burial. Other work on Brazilian and African lateritic profiles has used 
cosmogenic ${ }^{10} \mathrm{Be}$ and ${ }^{26} \mathrm{Al}$ to differentiate between autochthonous and allochthonous components of lateritic systems - and hence the role of in situ weathering and colluvial transport in their development, and to constrain models of stone-line formation (Braucher et al., 1998a, b, 2000). Cosmogenic isotope analysis has also been applied to calcretes using ${ }^{36} \mathrm{Cl}$, with the study by Liu et al. (1994) indicating, through an increase in age with depth, that at their site in southern Arizona calcretes develop by upward accumulation and that water movement is very limited once induration has occurred. The potential of cosmogenic isotope analysis to reveal complex components of weathering profile development is illustrated by the study of Schroeder et al. (2001) in the piedmont zone of Georgia, USA. Here a significantly younger age (maximum 8000 yr) for ${ }^{14} \mathrm{C}$ bound in gibbsite compared with near surface residence times for quartz, based on ${ }^{10} \mathrm{Be}$ and ${ }^{26} \mathrm{Al}$ inventories, of at least $90 \mathrm{ka}$ points to significant recrystallization of secondary minerals during weathering front propagation into bedrock.

\section{Soil production, erosion and landscape development}

The rate at which soil (regolith) is produced is a key geomorphological parameter because it is the entrainment and transport of unconsolidated material rather than the direct erosion of bedrock that dominates in most environments. Soil depth is a function of the rate of soil production and the rate of removal by physical erosion and solutional loss. But it has long been recognized that the rate of soil production is itself also influenced by soil depth (Gilbert, 1877), although the precise nature of this relationship has been disputed. The relationships between slope, soil depth, rate of soil production and rate of hillslope erosion are fundamental to understanding the surface processes controlling landscape evolution, and the ability of cosmogenic isotope analysis to provide quantitative insights into these processes and their relationships is likely to provide one of its most significant contributions to geomorphology. Already these applications are being exploited. For instance, in a study of regolith production on hillslopes in an alpine environment in Wyoming, USA using ${ }^{10} \mathrm{Be}$ and ${ }^{26} \mathrm{Al}$ concentrations from depth profiles, Small et al. (1999) have established that the rate of regolith production has been nearly twice as rapid under $\sim 0.9 \mathrm{~m}$ of regolith than that previously determined from erosion rates on bare rock surfaces from similar (although not identical) alpine environments in the western USA (Small et al., 1997).

Making the assumption that bedrock conversion to soil attains a steady state under a constant soil thickness, Heimsath et al. $(1997,1999)$ used cosmogenic ${ }^{10} \mathrm{Be}$ and ${ }^{26} \mathrm{Al}$ concentrations in bedrock at the base of the soil column to evaluate the relationship between soil production rate and soil depth. For their field area in northern California they found an exponential decline in production rate with increasing soil depth from $77 \mathrm{~mm} \mathrm{ka}^{-1}$ with no soil cover, to $7.7 \mathrm{~mm} \mathrm{ka}^{-1}$ under a soil depth of $1 \mathrm{~m}$. Although from their data they could not rule out a maximum in soil production rate under a thin soil cover (a long-standing notion in geomorphology (Carson and Kirkby, 1972)) they were able to confirm that peak soil production does occur very close to zero soil depth. Results from a similar study in southeastern Australia confirmed the exponential decline in rates of soil production with increasing soil depth (Heimsath et al., 2000).

Extending this approach to an intensively studied field site in the Oregon Coast Range, Heimsath et al. (2001a) concluded from a ${ }^{10} \mathrm{Be}$ - and ${ }^{26} \mathrm{Al}$-derived analysis of soil 
production rates that although there may be an approximately constant rate of landscape erosion over parts of the Oregon Coast Range, smaller-scale processes such as drainage competition and stochastic erosional events, especially by biogenic processes, lead to significant temporal and spatial variations in soil depth. Further applications in southeastern Australia illustrate how cosmogenic isotope data can be used to quantify long-term relationships between rates of soil production, bedrock incision, and regional erosion and regolith stripping (Heimsath et al., 2000, 2001b).

Another strategy for estimating soil accumulation and erosion rates is provided by depth profiles of cosmogenic nuclide concentrations in soils (Phillips et al., 1998; Phillips, 2000). Anomalously low erosion rates using this method can be produced from the inheritance of cosmogenic nuclides from old soils incorporated into colluvium, while bioturbation can produce depth profiles of cosmogenic nuclide concentration that are very similar to those associated with rapid soil accumulation. Fortunately, the distinctive profile produced through the rapid radioactive decay of in situ-produced ${ }^{14} \mathrm{C}$, when coupled with measurements of stable (e.g., ${ }^{21} \mathrm{Ne}$ ) or longer-lived isotopes (e.g., ${ }^{10} \mathrm{Be}$ ), can resolve the effects of both bioturbation and inheritance (Phillips, 2000). The potential for cosmogenic isotope data to elucidate specific processes operating in soils on hillslopes, especially when combined with other techniques, has been illustrated by Heimsath et al. (2002). They used cosmogenic nuclide concentrations of ${ }^{10} \mathrm{Be}$ and ${ }^{26} \mathrm{Al}$ to measure the overall downslope flux of soil material, in combination with single-grain OSL dating to track the movement of individual quartz grains in order to quantify the grain-scale mechanisms involved in the process of soil creep.

\section{Palaeoaltimetry}

A fundamental difficulty in testing models of long-term landscape development is the lack of data on land surface palaeoelevation. Without such data it is not possible to quantify changes in topography (in terms of elevation with respect to the geoid) over time and therefore test this key component of landscape evolution models. Since cosmogenic nuclide production rates are a function of altitude - or, more strictly, atmospheric pressure - accumulation is sensitive to changes in the elevation of a sample during exposure (Lal, 1991). Inferring palaeoaltimetry from measured concentrations of cosmogenic nuclides is therefore an exciting possibility (Gosse and Stone, 2001), but true palaeoaltimetry requires independent data on the exposure age and erosion rate of a sample, since only by constraining these two unknowns can a change in surface elevation of a sample since it was first exposed be calculated. Nonetheless, it is possible to evaluate particular combinations of surface exposure age and elevation change during the period of exposure. Such an application has been used in the Transantarctic Mountains, Antarctica to test the assertion of substantial surface uplift of supposed late Pliocene age Sirius Group glacial deposits and associated landscape elements at rates of up to $1000 \mathrm{~m} \mathrm{Ma}^{-1}$ over the past 3 Ma (Brown et al., 1991; Brook et al., 1995a; Ivy-Ochs et al., 1995; Bruno et al., 1997; Schäfer et al., 1999; Van der Wateren et al., 1999). The cosmogenic data can be interpreted as showing that either the Sirius Group deposits are of late Pliocene age, or there has been substantial surface uplift over the past $3 \mathrm{Ma}$, but not both. In other words the cosmogenic data provide a one-way test since, within the relevant timescale, high cosmogenic nuclide concentrations are incompatible with high 
surface uplift rates, whereas low concentrations do not require high surface uplift rates (because of the possibility of erosion reducing cosmogenic nuclide concentrations) (Brook et al., 1995a).

Incorporating the effect of surface uplift increases apparent exposure times, and this effect has been used to reconcile apparent differences between independent age constraints and cosmogenic exposure age estimates (Schäfer et al., 1999; Kober et al., 2002). More accurate palaeoaltimetry from cosmogenic nuclide data in the future will require a better understanding of the atmospheric pressure-altitude relationship for production than is currently available (Gosse and Stone, 2001), but will also require unusual circumstances where the exposure history is independently constrained.

\section{Facilities for cosmogenic isotope analysis}

The future expansion of applications of cosmogenic isotope analysis to geomorphology and Quaternary science will depend to a significant extent on the availability of facilities for sample preparation and isotope measurement. There are a growing number of such facilities worldwide, with a concentration in the USA but including Australia, Canada, France, Germany, Japan and Switzerland. In the UK there are dedicated AMS target preparation laboratories for ${ }^{10} \mathrm{Be} /{ }^{26} \mathrm{Al}$ and ${ }^{36} \mathrm{Cl}$ in the Department of Geography at Edinburgh University, but the widespread adoption of cosmogenic isotope analysis in the $\mathrm{UK}$, as elsewhere, will require a substantial increase in target preparation capability. Sample preparation for the stable noble gas cosmogenic isotopes is less demanding and can be accomplished with standard laboratory facilities.

In terms of the measurement of cosmogenic isotopes, the high-sensitivity noble gas mass spectrometres capable of measuring ${ }^{3} \mathrm{He}$ and ${ }^{21} \mathrm{Ne}$ are relatively widely available, but there are difficulties in using such machines where they have also been used for measuring irradiated samples for ${ }^{40} \mathrm{Ar} /{ }^{39} \mathrm{Ar}$ dating, and the number of machines dedicated to cosmogenic ${ }^{3} \mathrm{He}$ and ${ }^{21} \mathrm{Ne}$ is limited. For the measurement of cosmogenic radioisotopes, the tandem electrostatic accelerators most commonly used range in maximum terminal voltage from less than $3 \mathrm{MV}$ to $16 \mathrm{MV}$. The lower voltage accelerators ( $\sim 3 \mathrm{MV}$ or less) are commonly used routinely for ${ }^{14} \mathrm{C}$, but they can also be used to measure ${ }^{10} \mathrm{Be}$ and ${ }^{26} \mathrm{Al}$. Intermediate-sized machines (5-9 MV) can potentially measure the full range of cosmogenic isotopes, although the higher energies available from the largest machines (10 MV or more) are particularly advantageous for the measurement of ${ }^{36} \mathrm{Cl}$ (Fifield, 1999). With a maximum terminal voltage of $5 \mathrm{MV}$, the Joint Infrastructure Fund (NERC)-financed AMS at the Scottish Universities Environmental Research Centre AMS Facility, East Kilbride, is in the intermediate category and will have a capability across the range of cosmogenic isotopes commonly used in Earth and environmental science applications. Although there are currently over 40 AMS facilities worldwide (Tuniz et al., 1998), several specialize in radiocarbon dating, and relatively few currently undertake significant numbers of measurements across a range of cosmogenic isotopes for Earth and environmental science applications (Table 4). 


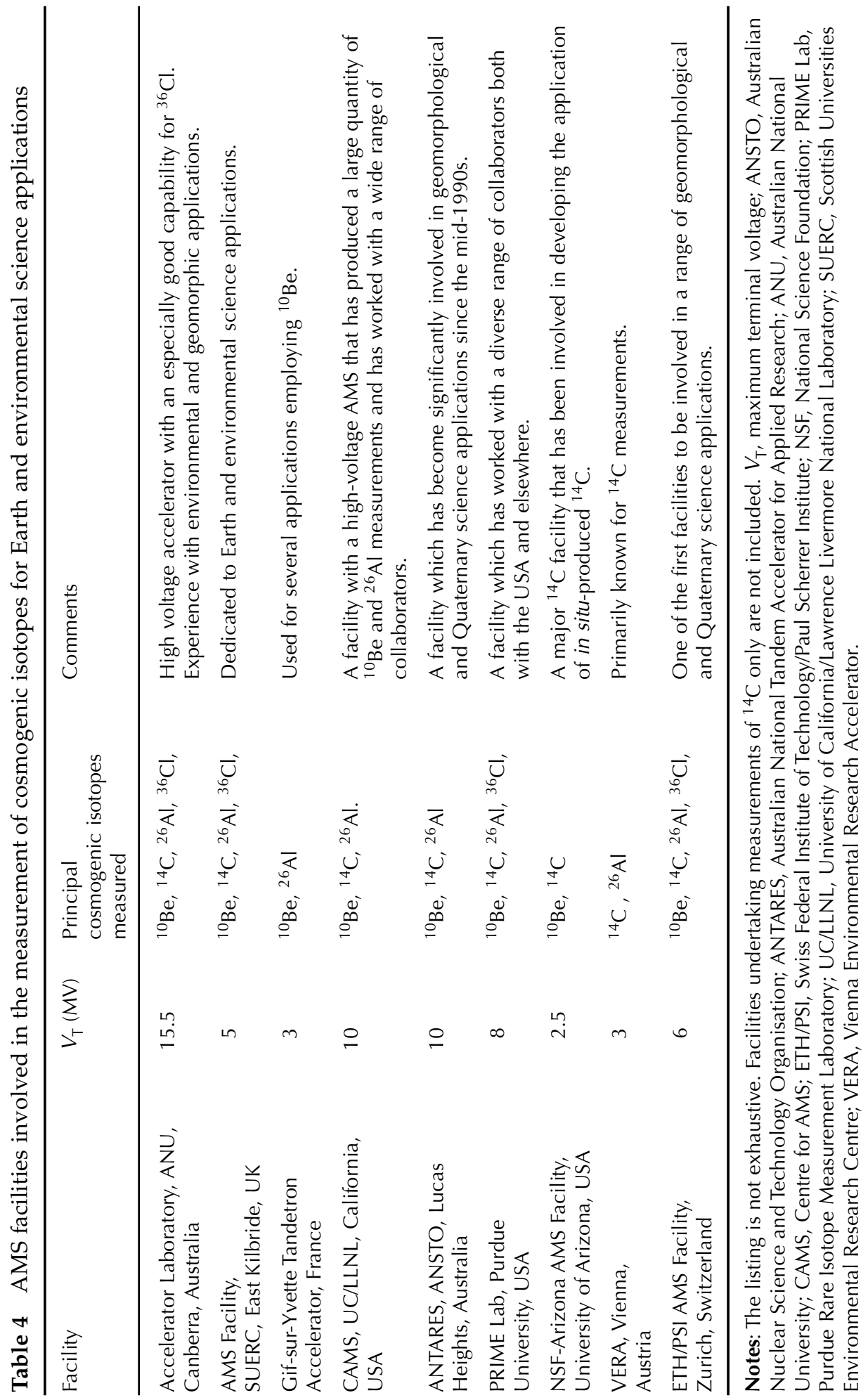




\section{Conclusions and future directions}

Over the past decade there has been a remarkable growth in applications of cosmogenic isotope analysis in geomorphology and Quaternary science. This has arisen very largely from the capability to provide chronological constraints where none were possible before, both in terms of the timescales that can be addressed and because the technique can be applied to a range of minerals that are virtually ubiquitous on the Earth's surface. However, this is still a rapidly developing technique and there are exciting prospects for the immediate future.

One of these, which underpins all applications of cosmogenic isotope analysis, is improved data on production rates and a better understanding of the spatial and temporal factors that control them. The importance of establishing a community-wide consensus on cosmogenic isotope production rates used in the estimation of exposure ages and denudation rates is now regarded as a major priority, with the ultimate objective of producing cosmogenic exposure ages with errors of $5 \%$ or less. Coupled with the analysis of a larger number of samples for a particular problem, and the measurement of several isotopes in the same sample, this greater accuracy will provide the kind of tight chronological constraints necessary to answer key questions in recent Earth history.

Another area of active research involves muon production (Heisinger et al., 2002a, b, c). The greater attenuation length of muon interactions compared with spallation means that muogenic production requires more time to reach secular equilibrium with respect to losses from denudation and radioactive decay. Consequently muogenic production is less sensitive to short-timescale perturbations in denudation, and therefore yields rates averaged over longer periods of time than the spallation-produced component. This opens the possibility of comparing denudation rates over different timescales from vertical sequences of samples (Stone et al., 1994; Brown et al., 1995b; Heisinger and Nolte, 2000).

The issue of how rates of denudation might vary over different timescales can be taken much further by combining cosmogenic isotope analysis with other techniques that address both shorter and longer time ranges (Kirchner et al., 2001). Such information has important practical implications since denudation rates over 'cosmogenic' timescales can provide a valuable benchmark for recent anthropogenic perturbations of drainage basins. The multi-timescale approach has already been applied in the Nanga Parbat area of the western Himalayas where the rate of incision of the Indus River estimated from cosmogenic exposure ages of strath terraces was compared with longer-term denudation rates derived from fission-track thermochronology (Burbank et al., 1996). The combination of cosmogenic isotope analysis and thermochronology has also been applied to landscapes in far less active tectonic settings (Belton et al., 2000; Cockburn et al., 2000; Brown et al., 2002). Such comparative studies have to be undertaken with care when using site-specific sampling for cosmogenic isotope analysis given the much larger spatial scale to which thermochronology applies, but sampling from key landscape elements, such as escarpment faces and summits, can be fruitfully integrated with data on regional patterns of denudation derived from thermochronology (Cockburn et al., 2000).

Finally, expanded applications of catchment-averaged denudation rates studies are also likely in the future. The ability to document the exposure, transport and burial of 
sediment in fluvial systems over timescales of $10^{3}-10^{6}$ yr opens up a whole suite of possibilities for developing an understanding of drainage basin processes over the timescales relevant to significant landscape change (Granger, 2002). Particularly valuable for addressing the more recent part of this time range will be the wider use of in-situ-produced ${ }^{14} \mathrm{C}$ (Jull et al., 1989, 1992, 1994b; Handwerger et al., 1999; Lal and Jull, 2001). Recent technical advances (Lifton et al., 2001; 2002) are now making it possible to pair this short-lived radioisotope with cosmogenic nuclides with much longer half-lives in order to provide far more sensitivity in the detection of complex exposure histories.

\section{Acknowledgements}

We thank Bill Phillips and Arjun Heimsath for comments on the manuscript, and acknowledge financial support from the Natural Environment Research Council (HAPC/MAS), the Australian Research Council (HAPC), the Leverhulme Trust (HAPC) and the Carnegie Trust for the Universities of Scotland (MAS).

\section{References}

\begin{abstract}
Albrecht, A., Herzog, G.F., Klein, J., DezfoulyArjomandy, B. and Goff, F. 1993: Quaternary erosion and cosmic-ray erosion history derived from ${ }^{10} \mathrm{Be}$ and ${ }^{26} \mathrm{Al}$ produced in situ: an example from the Pajarito plateau, Valles caldera region. Geology 21, 551-54.
\end{abstract}

Anderson, R.S., Repka, J.L. and Dick, G.S. 1996: Explicit treatment of inheritance in dating depositional surfaces using in situ ${ }^{10} \mathrm{Be}$ and ${ }^{26} \mathrm{Al}$. Geology 24, 47-51.

Anthony, E.Y. and Poths, J. 1992: ${ }^{3} \mathrm{He}$ surface exposure dating and its implications for magma evolution in the Potrillo volcanic field, Rio Grande Rift, New Mexico, USA. Geochimica et Cosmochimica Acta 56, 4105-108.

Ballantyne, C., Stone, J.O.H. and Fifield, L.K. 1998: Cosmogenic Cl-36 dating of postglacial landsliding at the Storr, Isle of Skye, Scotland. The Holocene 8, 347-51.

Barnard, P.L., Owen, L.A., Sharma, M.C. and Finkel, R.C. 2001: Natural and human-induced landsliding in the Garhwal Himalaya of northern India. Geomorphology 40, 21-35.

Barrows, T.T., Stone, J.O., Fifield, L.K. and Cresswell, R.G. 2001: Late Pleistocene glaciation of the Kosciuszko Massif, Snowy Mountains, Australia. Quaternary Research 55, 179-89.

-_-_ 2002: The timing of the Last Glacial Maximum in Australia. Quaternary Science Reviews 21, 159-73.

Bell, J.W., Brune, J.N., Liu, T., Zreda, M. and
Yount, J.C. 1998: Dating precariously balanced rocks in seismically active parts of California and Nevada. Geology 26, 495-98.

Belton, D.X., Brown, R.W., Kohn, B.P. and Fink, D. 2000: The first quantitative erosion rate estimates from '....the oldest persisting ... landforms in the world ...'. Geological Society of Australia Abstracts 58, 24-28.

Bierman, P.R. 1994: Using in situ produced cosmogenic isotopes to estimate rates of landscape evolution: a review from the geomorphic perspective. Journal of Geophysical Research 99, 13 885-96.

Bierman, P. and Caffee, M. 2001: Slow rates of rock surface erosion and sediment production across the Namib Desert and escarpment, southern Africa. American Journal of Science 301, 326-58.

- 2002: Cosmogenic exposure and erosion history of Australian bedrock landforms. Geological Society of America Bulletin 114, 787-803.

Bierman, P. and Gillespie, A. 1991: Range fires a significant factor in exposure age determination and geomorphic surface evolution. Geology 19, 641-44.

Bierman, P. and Steig, E.J. 1996: Estimating rates of denudation using cosmogenic isotope abundances in sediment. Earth Surface Processes and Landforms 21, 125-39.

Bierman, P. and Turner, J. 1995: ${ }^{10} \mathrm{Be}$ and ${ }^{26} \mathrm{Al}$ evidence for exceptionally low rates of Australian bedrock erosion and the likely 
existence of pre-Pleistocene landscapes. Quaternary Research 44, 378-82.

Bierman, P.R., Gillespie, A.R. and Caffee, M.W. 1995: Cosmogenic ages for earthquake recurrence intervals and debris flow fan deposition, Owens Valley, California. Science 270, 447-50.

Bierman, P.R., Marsella, K.A., Patterson, C., Davis, P.T. and Caffee, M. 1999: MidPleistocene cosmogenic minimum age limits for pre-Wisconsin glacial surfaces in southwestern Minnesota and southern Baffin Island: a multiple nuclide approach. Geomorphology 27, 25-40.

Bourlès, D.L., Braucher, R., Brown, E.T., Kalvoda, J. and Mercier, J.L. 2002: Younger Dryas glacial expansion in the discontinuously glaciated area of Western and Central Europe. Geochimica et Cosmochimica Acta 66, S1, A98.

Bowen, D.Q., Phillips, F.M., McCabe, A.M., Knutz, P.C. and Sykes, G.A. 2002: New data for the last Glacial Maximum in Great Britain and Ireland. Quaternary Science Reviews 21, 89-101.

Braucher, R., Bourlès, D.L., Colin, F., Brown, E.T. and Boulange, B. 1998a: Brazilian laterite dynamics using in situ produced ${ }^{10} \mathrm{Be}$. Earth and Planetary Science Letters 163, 197-205.

Braucher, R., Colin, F., Brown, E.T., Bourlès, D.L., Bamba, O., Raisbeck, G.M., Yiou, F. and Koud, J.M. 1998b: African laterite dynamics suing in situ produced ${ }^{10} \mathrm{Be}$. Geochimica et Cosmochimica Acta 62, 1501-507.

Braucher, R., Bourlès, D.L., Brown, E.T., Colin, F., Muller, J.P., Braun, J.J., Delaune, M., Edou Minko, A., Lescouet, C., Raisbeck, G.M. and Yiou, F. 2000: Application of in situ produced cosmogenic ${ }^{10} \mathrm{Be}$ and ${ }^{26} \mathrm{Al}$ to the study of lateritic soil development in tropical forest: theory and examples from Cameroon and Gabon. Chemical Geology 170, 95-111.

Briner, J.P. and Swanson, T.W. 1998: Using inherited cosmogenic ${ }^{36} \mathrm{Cl}$ to constrain glacial erosion rates of the Cordelleran ice sheet. Geology 26, 3-6.

Briner, J.P., Swanson, T.W. and Caffee, M. 2001: Late Pleistocene cosmogenic Cl-36 glacial chronology of the southwestern Ahklun mountains, Alaska. Quaternary Research 56, 148-54.

Briner, J.P., Kaufman, D.S., Werner, A., Caffee, M., Levy, L., Manley, W.F., Kaplan, M.R. and Finkel, R.C. 2002: Glacier readvance during the late glacial (Younger Dryas?) in the Ahklun Mountains, southwestern Alaska. Geology 30, 679-82

Brook, E.J. and Kurz, M.D. 1993: Surfaceexposure chronology using in situ cosmogenic
${ }^{3} \mathrm{He}$ in Antarctic quartz sandstone boulders. Quaternary Research 39, 1-10.

Brook, E.J., Kurz, M.D., Ackert, R.P., Denton, G.H., Brown, E.T., Raisbeck, G.M. and Yiou, F. 1993: Chronology of Taylor glacier advances in Arena Valley, Antarctica, using in situ cosmogenic ${ }^{3} \mathrm{He}$ and ${ }^{10} \mathrm{Be}$. Quaternary Research $39,11-23$.

Brook, E.J., Brown, E.T., Kurz, M.D., Ackert, R.P., Raisbeck, G.M. and Yiou, F. 1995a: Constraints on age, erosion and uplift of Neogene glacial deposits in the Transantarctic Mountains determined from in situ cosmogenic ${ }^{10} \mathrm{Be}$ and ${ }^{26} \mathrm{Al}$. Geology 23, 1063-66.

Brook, E.J., Kurz, M.D., Ackert, R.P., Raisbeck, G. and Yiou, F. 1995b: Cosmogenic nuclides exposure ages and glacial history of late Quaternary Ross Sea drift in McMurdo Sound, Antarctica. Earth and Planetary Science Letters 131, 41-56.

Brook, E.J., Nesje, A., Lehman, S., Raisbeck, G. and Yiou, F. 1996: Cosmogenic exposure ages along a vertical transect in western Norway: implications for the height of the Fennoscandian Icesheet. Geology 24, 207-10.

Brown, E.T., Edmond, J.M., Raisbeck, G.M., Yiou, F., Kurz, M.D. and Brook, E.J. 1991: Examination of surface exposure ages of Antarctic moraines using in situ produced ${ }^{10} \mathrm{Be}$ and ${ }^{26} \mathrm{Al}$. Geochimica et Cosmochimica Acta 55, 2269-83.

Brown, E.T., Brook, E.J., Raisbeck, G.M. Yiou, F. and Kurz, M.D. 1992: Effective attenuation lengths of cosmic rays producing ${ }^{10} \mathrm{Be}$ and ${ }^{26} \mathrm{Al}$ in quartz: implications for exposure age dating. Geophysical Research Letters 19, 369-72.

Brown, E.T., Bourlès, D.L., Colin, F., Sanfo, Z., Raisbeck, G.M. and Yiou, F. 1994: The development of iron crust lateritic systems in Burkino Faso, West Africa examined with in situ produced cosmogenic nuclides. Earth and Planetary Science Letters 124, 19-33.

Brown, E.T., Stallard, R.F., Larsen, M.C., Raisbeck, G.M. and Yiou, F. 1995a: Denudation rates determined from the accumulation of siteproduced ${ }^{10} \mathrm{Be}$ in the Luquillo Experimental Forest, Puerto Rico. Earth and Planetary Science Letters 129, 193-202.

Brown, E.T., Bourlès, D.L., Colin, F., Raisbeck, G.M., Yiou, F. and Desgarceaux, S. 1995b: Evidence for muon-induced production of ${ }^{10} \mathrm{Be}$ in near-surface rocks from the Congo. Geophysical Research Letters 22, 703-706.

Brown, E.T., Bourlès, D.L., Burchfiel, B.C., Qidong, D., Jun, Li., Molnar, P., Raisbeck, G.M. and Yiou, F. 1998a: Estimation of slip 
rates in the southern Tien Shan using cosmic ray exposure dates of abandoned alluvial fans. Geological Society of America Bulletin 110, 377-86.

Brown, E.T., Stallard, R.F., Larsen, M.C., Bourlès, D.L. and Raisbeck, G.M. 1998b: Determination of predevelopment denudation rates of an agricultural watershed (Cayaguas River, Puerto Rico) using in-situ-produced Be-10 in river borne quartz. Earth and Planetary Science Letters 160, 723-28.

Brown, R.W., Cockburn, H.A.P., Kohn, B.P., Belton, D.X., Fink, D., Gleadow, A.J.W. and Summerfield, M.A. 2002: Combining low temperature apatite thermochronology and cosmogenic isotope analysis in quantitative landscape evolution studies. Geochimica et Cosmochimica Acta 66, S1, A106.

Bruno, L.A., Baur, H., Graf, T., Schlüchter, C., Signer, P. and Wieler, R. 1997: Dating of Sirius Group tillites in the Antarctic Dry Valleys with cosmogenic ${ }^{3} \mathrm{He}$ and ${ }^{21} \mathrm{Ne}$. Earth and Planetary Science Letters 147, 37-54.

Burbank, D.W., Leland, J., Fielding, E., Anderson, R.S., Brozovic, R.S., Reid, N. and Duncan, C. 1996: Bedrock incision, rock uplift and threshold hillslopes in the northwestern Himalayas. Nature 379, 505-10.

Carson, M.A. and Kirkby, M.J. 1972: Hillslope form and process. Cambridge: Cambridge University Press.

Cerling, T.E. 1990: Dating geomorphic surfaces using cosmogenic ${ }^{3}$ He. Quaternary Research 33, 148-56.

Cerling, T.E. and Craig, H. 1994a: Geomorphology and in-situ cosmogenic isotopes. Annual Review of Earth and Planetary Science 22, 273-317.

- 1994b: Cosmogenic ${ }^{3} \mathrm{He}$ production rates from 39 to 46 degrees latitude, western USA and France. Geochimica et Cosmochimica Acta 58, 249-55.

Cerling, T.E., Poreda, R.O. and Rathburn, S.L. 1994: Cosmogenic ${ }^{3} \mathrm{He}$ and ${ }^{21} \mathrm{Ne}$ age of the Big Lost River flood Snake River Plain, Idaho. Geology 22, 227-30.

Cerling, T.E., Webb, R.H., Poreda, R.J., Rigby, A.D. and Melis, T.S. 1999: Cosmogenic ${ }^{3} \mathrm{He}$ ages and frequency of late Holocene debris flows from Prospect Canyon, Grand Canyon, USA. Geomorphology 27, 93-111.

Chadwick, O.A., Hall, R.D. and Phillips, F.M. 1997: Chronology of Pleistocene glacial advances in the central Rocky Mountains. Geological Society of America Bulletin 109, 1443-52.

Clapp, E.M., Bierman, P.R., Schick, A.P., Lekach,
J., Enzel, Y. and Caffee, M. 2000: Sediment yield exceeds sediment production in arid region drainage basins. Geology 28, 995-98.

Clapp, E.M., Bierman, P.R., Nichols, K.K., Pavich, M. and Caffee, M. 2001: Rates of sediment supply to arroyos from upland erosion determined using in situ produced cosmogenic Be-10 and Al-26. Quaternary Research 55, 235-45.

Clapp, E.M., Bierman, P.R. and Caffee, M. 2002: Using ${ }^{10} \mathrm{Be}$ and ${ }^{26} \mathrm{Al}$ to determine sediment generation rates and identify sediment source areas in an arid region drainage basin. Geomorphology 45, 89-104.

Clark, D.H., Bierman, P.R. and Larsen, P. 1995: Improving in situ cosmogenic chronometres. Quaternary Research 44, 367-77.

Cockburn, H.A.P. and Summerfield, M.A. 2000: Landscape evolution in Namibia: constraining denudation with in-situ cosmogenic nuclides. Communications of the Geological Survey of Namibia 12, 403-408.

Cockburn, H.A.P., Seidl, M.A. and Summerfield, M.A. 1999: Quantifying denudation rates on inselbergs in the central Namib Desert using in situ-produced cosmogenic ${ }^{10} \mathrm{Be}$ and ${ }^{26} \mathrm{Al}$. Geology 27, 399-402.

Cockburn, H.A.P., Brown, R.W., Summerfield, M.A. and Seidl, M.A. 2000: Quantifying passive margin denudation and landscape development using a combined fission-track thermochronology and cosmogenic isotope analysis approach. Earth and Planetary Science Letters 179, 429-35.

Craig, H. and Poreda, R. 1986: Cosmogenic ${ }^{3} \mathrm{He}$ in terrestrial rocks: The summit lavas of Maui. National Academy of Science Proceedings 83, 1970-74.

Davis, P.T., Bierman, P.R., Marsella, K.A., Caffee, M.W. and Southon, J.R. 1999: Cosmogenic analysis of glacial terrains in the eastern Canadian Arctic: a test for inherited nuclides and the effectiveness of glacial erosion. Annals of Glaciology 28, 181-88.

Davis, R. and Schaffer, O.A. 1955: Chlorine-36 in nature. Annals of the New York Academy of Science 62, 105-22.

Desilets, D., Zreda, M. and Lifton, N.A. 2001: Comment on scaling factors for production rates of in situ produced cosmogenic nuclides: a critical reevaluation. By Tibor Dunai. Earth and Planetary Science Letters 188, 283-87.

Dickin, A.P. 1995: Radiogenic isotope geology. Cambridge: Cambridge University Press, 490 pp. 
Dunai, T.J. 2000: Scaling factors for production rates of in situ produced cosmogenic nuclides: a critical reevaluation. Earth and Planetary Science Letters 176, 157-69.

_ 2001a: Reply to Comment on scaling factors for production rates of in situ produced cosmogenic nuclides: a critical reevaluation. By Desilets, D., Zreda, M., Lifton, N.A. Earth and Planetary Science Letters 188, 289-98.

_ 2001b: Influence of secular variation of the geomagnetic field on production rates of in-situ produced cosmogenic nuclides. Earth and Planetary Science Letters 193, 197-212.

- 2002: Scaling factors for in-situ cosmogenic production, an attempt to reach a working consensus. Geochimica et Cosmochimica Acta 66, S1, A200.

Dunai, T. and Wijbrans, J.R. 2000: Long-term cosmogenic ${ }^{3} \mathrm{He}$ production rates (152 ka-1.35 Ma) from ${ }^{40} \mathrm{Ar} /{ }^{39} \mathrm{Ar}$ dated basalt flows at 29 degrees N latitude. Earth and Planetary Science Letters 176, 147-56.

Dunne, J., Elmore, D. and Muzikar, P. 1999: Scaling factors for the rates of production of cosmogenic nuclides for geometric shielding and attenuation at depth on sloped surfaces. Geomorphology 27, 3-12.

Elmore, D. and Phillips, F.M. 1987: Accelerator mass spectrometry for measurement of longlived radioisotopes. Science 236, 543-50.

Eppes, M.C. and Harrison, J.B.J. 1999: Spatial variability of soils developing on basalt flows in the Potrillo volcanic field, southern New Mexico: prelude to a chronosequence study. Earth Surface Processes and Landforms 24, 1009-24.

Fabel, D. and Harbor, J. 1999: The use of in-situ produced cosmogenic radionuclides in glaciology and glacial geomorphology. Annals of Glaciology 28, 103-10.

Fabel, D., Stone, J., Fifield, L.K. and Cresswell, R. 1997: Deglaciation of the Vestfold Hills, East Antarctica: preliminary evidence from exposure dating of three subglacial erratics. In Ricci, C.A., editor, The Antarctic region: geological evolution and process. Siena: Terra Antartica Publications, 823-34.

Fabel, D., Stroeven, A.P., Harbor, J., Kleman, J., Elmore, D. and Fink, D. 2002: Landscape preservation under Fennoscandian ice sheets determined from in situ produced ${ }^{10} \mathrm{Be}$ and ${ }^{26} \mathrm{Al}$. Earth and Planetary Science Letters 201, 397-406.

Fenton, C.R., Webb, R.H., Pearthree, P.A., Cerling, T.E. and Poreda, R.J. 2001:
Displacement rates on the Toroweap and hurricane faults: implications for Quaternary downcutting in the Grand Canyon, Arizona. Geology 29 1035-38.

Fifield, L.K. 1999: Accelerator mass spectrometry and its applications. Reports on Progress in Physics 62, 1223-74.

Fink, D., Middleton, R., Klein, J. and Sharma, P. 1990: ${ }^{41} \mathrm{Ca}$ measurement by accelerator mass spectrometry and applications. Nuclear Instruments and Methods in Physics Research B 47, 79-96.

Finkel, R.C. and Suter, M. 1993: AMS in the Earth Sciences, techniques and applications. Advances in Analytical Geochemistry 1,1-114.

Fleming, A., Summerfield, M.A., Stone, J.O., Fifield, K. and Cresswell, R.G. 1999: Denudation rates for the southern Drakensberg escarpment, SE Africa, derived from in-situproduced cosmogenic ${ }^{36} \mathrm{Cl}$ : initial results. Journal of the Geological Society, London 156, 209-12.

Fröhlich, K. and Lübert, J. 1973: Uber die Möglichkeit der Messung von Erosionsgeshwindigkeiten an oberflächengesteinen mit den natürlichen Radionuckliden ${ }^{41} \mathrm{Ca}$ und ${ }^{39} \mathrm{Ar}$. Zeitschrift für Angewandte Geologie 19, 550.

Gilbert, G.K. 1877: Report on the geology of the Henry Mountains (Utah). Washington DC: United States Geological Survey.

Gosse, J.C. and Phillips, F.M. 2001: Terrestrial in situ cosmogenic nuclides: theory and application. Quaternary Science Reviews 20, 1475-560.

Gosse, J.C. and Stone, J.O. 2001: Terrestrial cosmogenic nuclide methods passing milestones toward palaeo-altimetry. Eos 82, 82-89.

Gosse, J.C. and Willenbring, J. 2002: Glacier erosion factory: using ${ }^{26} \mathrm{Al} /{ }^{10} \mathrm{Be}$, soils, and geomorphology to study relief development. Geochimica et Cosmochimica Acta 66, S1, A287.

Gosse, J.C., Evenson, E.B., Klein, J., Lawn, B. and Middleton, R. 1995a: Precise cosmogenic ${ }^{10} \mathrm{Be}$ measurements in western North America: support fort a global Younger Dryas cooling event. Geology 23, 877-80.

Gosse, J.C., Klein, J., Evenson, J., Lawn, B. and Middleton, R. $1995 \mathrm{~b}:{ }^{10} \mathrm{Be}$ dating of the duration and retreat of the last Pinedale Glacial sequence. Science 268, 1329-33.

Gosse, J.C., Reedy, R.C., Harrington, C.D. and Poths, J. 1996: Overview of the workshop on secular variations in production rates of cosmogenic nuclides on Earth. Radiocarbon 38, 135-47.

Granger, D.E. 2002: Spatially averaged erosion 
rates from cosmogenic nuclides in sediments, ten years later. Geochimica et Cosmochimica Acta 66, S1, A288.

Granger, D.E. and Muzikar, P.F. 2001: Dating sediment burial with in situ-produced cosmogenic nuclides: theory, techniques, and limitations. Earth and Planetary Science Letters $188,269-81$.

Granger, D.E. and Smith, A.L. 2000: Dating buried sediments using radioactive decay and muogenic production of ${ }^{26} \mathrm{Al}$ and ${ }^{10} \mathrm{Be}$. Nuclear Instruments and Methods in Physics Research $B$ $172,822-26$.

Granger, D.E., Kirchner, J.W. and Finkel, R.C. 1996: Spatially averaged long-term erosion rates measured from in situ-produced cosmogenic nuclides in alluvial sediment. The Journal of Geology 104, 249-57.

- 1997: Quaternary downcutting rate of the New River, Virginia, measured from differential decay of cosmogenic ${ }^{26} \mathrm{Al}$ and ${ }^{10} \mathrm{Be}$ in cavedeposited alluvium. Geology 25, 107-10.

Granger, D.E., Fabel, D. and Palmer, A.N. 2001a: Pliocene-Pleistocene incision of the Green River, Kentucky, determined from radioactive decay of cosmogenic ${ }^{26} \mathrm{Al}$ and ${ }^{10} \mathrm{Be}$ in Mammoth Cave sediments. Geological Society of America Bulletin 113, 825-36.

Granger, D.E., Riebe, C.S., Kirchner, J.W. and Finkel, R.C. 2001b: Modulation of erosion on steep granitic slopes by boulder armouring, as revealed by cosmogenic ${ }^{26} \mathrm{Al}$ and ${ }^{10} \mathrm{Be}$. Earth and Planetary Science Letters 186, 269-81.

Gualtieri, L. and Brigham-Grette, J. 2001: The age and origin of the Little Diomede Island upland surface. Arctic 54, 12-21.

Gualtieri, L., Glushkova, O. and BrighamGrette, J. 2000: Evidence for restricted iceextent during the last glacial maximum in the Koryak Mountains of Chukotka, far eastern Russia. Geological Society of America Bulletin 112, 1106-18.

Hallet, B. and Putkonen, J. 1994: Surface dating of dynamic landforms: young boulders on ageing moraines. Science 265, 937-40.

Hancock, G.S., Anderson, R.S., Chadwick, O.A. and Finkel, R.C. 1999: Dating fluvial terraces with ${ }^{10} \mathrm{Be}$ and ${ }^{26} \mathrm{Al}$ profiles: application to the Wind River, Wyoming. Geomorphology 27, 41-60.

Handwerger, D.A., Cerling, T.E. and Bruhn, R.L. 1999: Cosmogenic ${ }^{14} \mathrm{C}$ in carbonate rocks. Geomorphology 27, 13-24.

Heimsath, A.M., Dietrich, W.E., Nishiizumi, K. and Finkel, R.C. 1997: The soil production function and landscape equilibrium. Nature 388, 358-61.

_- 1999: Cosmogenic nuclides, topography, and the spatial variation of soil depth. Geomorphology 27, 151-72.

Heimsath, A.M., Chappell, J., Dietrich, W.E., Nishiizumi, K. and Finkel, R.C. 2000: Soil production on a retreating escarpment in southeastern Australia. Geology 28, 787-90.

Heimsath, A.M., Dietrich, W.E., Nishiizumi, K and Finkel, R.C. 2001a: Stochastic processes of soil production and transport: erosion rates, topographic variation and cosmogenic nuclides in the Oregon Coast Range. Earth Surface Processes and Landforms 26, 531-52.

Heimsath, A.M., Chappell, J. and Dietrich, W.E. 2001b: Late Quaternary erosion in southeastern Australia: a field example using cosmogenic nuclides. Quaternary International 83, 169-85.

Heimsath, A.M, Chappell, J., Spooner, N.A. and Questiaux, D.G. 2002: Creeping soil. Geology 30, 111-14.

Heisinger, B. and Nolte, E. 2000: Cosmogenic in situ production of radionuclides: exposure ages and erosion rates. Nuclear Instruments and Methods in Physics Research B 172, 790-95.

Heisinger, B., Lal, D., Jull, A.J.T., Kubik, P., IvyOchs, S., Neumaier, S., Knie, K., Lazarev, V. and Nolte, E. 2002a: Production of selected cosmogenic radionuclides by muons 1 . Fast muons. Earth and Planetary Science Letters 200, 345-55.

Heisinger, B., Lal, D., Jull, A.J.T., Kubik, P., IvyOchs, S., Knie, K. and Nolte, E. 2002b: Production of selected cosmogenic radionuclides by muons 2. Capture of negative muons. Earth and Planetary Science Letters 200, 357-69.

Heisinger, B., Lal, D., Jull, A.J.T., Kubik, P.W., Ivy-Ochs, S., Neumaier, S., Knie, K., Lazarev, V. and Nolte, E. 2002c: Production of selected cosmogenic radionuclides by muons. Geochimica et Cosmochimica Acta 66, S1, A558.

Hermanns, R.L., Trauth, M.H., Niedermann, S., McWilliams, M. and Strecker, M.R. 2000: Tephrochronologic constraints on temporal distribution of large landslides in northwest Argentina. Journal of Geology 108, 35-52.

Hermanns, R.L., Niedermann, S., Villanueva Garcia, A., Sosa Gomez, J and Strecker, M.R. 2001: Neotectonics and catastrophic failure of mountain fronts in the southern intra-Andean Puna Plateau, Argentina. Geology 29, 619-23.

Hetzel, R., Niedermann, S., Ivy-Ochs, S., Kubik, P.W., Tao, M. and Gao, B. 2002a: ${ }^{21} \mathrm{Ne}$ versus ${ }^{10} \mathrm{Be}$ and ${ }^{26} \mathrm{Al}$ exposure ages of fluvial terraces: 
the influence of crustal $\mathrm{Ne}$ in quartz. Earth and Planetary Science Letters 201, 575-91.

Hetzel R., Niedermann, S., Tao, M., Kubik, P., Ivy-Ochs, S., Gao, B. and Strecker, M.R. 2002b: Low slip rates and long-term preservation of geomorphic features in Central Asia. Nature 417, 428-32.

Hindmarsh, R.C.A., van der Wateren, F.W. and Vebers, A.L.L.M. 1998: Sublimation of ice through sediment in Beacon Valley, Antarctica. Geografiska Annaler Series A: Physical Geography 80, 209-19.

Ivy-Ochs, S., Schlüchter, C., Kubik, P., DittrichHannen, B. and Beer, J. 1995: Minimum ${ }^{10} \mathrm{Be}$ exposure ages of early Pliocene for the Table Mountain plateau and the Sirius Group at Mount Fleming, Dry Valleys, Antarctica. Geology 23, 1007-19

Ivy-Ochs, S., Schlüchter, C., Kubik, P., Synal, HA, Beer, J. and Kerschner, H. 1996: The exposure age of an Egesen moraine at Julier Pass, Switzerland, measured with the cosmogenic nuclides ${ }^{10} \mathrm{Be},{ }^{26} \mathrm{Al}$ and ${ }^{36} \mathrm{Cl}$. Eclogae und Geologie Helvetica 89, 1049-63.

Ivy-Ochs, S., Schlüchter, C., Prentice, M., Kubik, P. and Beer, J. 1997: ${ }^{10} \mathrm{Be}$ and ${ }^{26} \mathrm{Al}$ exposure ages for the Sirius Group at Mount Fleming, Mount Feather and Table Mountain and the Plateau Surface at Table Mountain. In Ricci, C.A., editor, The Antarctic region: geological evolution and process. Siena: Terra Antartica Publications, 1153-58.

Ivy-Ochs, S., Heuberger, H., Kubik, P.W., Kerschner, H., Bonani, G., Frank, M. and Schlüchter, C. 1998: The age of the Köfels event. Relative ${ }^{14} \mathrm{C}$ and cosmogenic isotope dating of an early Holocene landslide in the central Alps (Tyrol, Austria). Zeitschrift für Gletscherkunde und Glazialgeologie 34, 57-68.

Ivy-Ochs, S., Schlüchter, C., Kubik, P.W. and Denton, G.H. 1999: Moraine exposure dates imply synchronous Younger Dryas glacier advance in the European Alps and in the Southern Alps of New Zealand. Geografiska Annaler Series A: Physical Geography 81, 313-23.

Jackson, J., Ritz, J.F., Siame, L., Raisbeck, G., Yiou, Y., Norris, R., Youngson, J. and Bennet, E. 2002: Fault growth and landscape development rates in Otago, New Zealand, using in situ cosmogenic ${ }^{10} \mathrm{Be}$. Earth and Planetary Science Letters 195, 185-93.

Jackson, L.E., Phillips, F.M., Shimamura, K. and Little, E.C. 1997: Cosmogenic ${ }^{36} \mathrm{Cl}$ dating of the Foothills erratics train, Alberta, Canada. Geology 25, 195-98.
Jackson, L.E., Phillips, F.M. and Little, E.C. 1999: Cosmogenic ${ }^{36} \mathrm{Cl}$ dating of the maximum limit of the Laurentide Ice Sheet in southwestern Alberta. Canadian Journal of Earth Science 36, 1347-56.

James, L.A., Fabel, D., Dahms, D. and Elmore, D. 2002: Late Pleistocene glaciation in the northwestern Sierra Nevada, California. Quaternary Research 57, 409-19.

Jull, A.J.T., Donahue, D.J., Linick, T.W. and Wilson, G.C. 1989: Spallogenic ${ }^{14} \mathrm{C}$ in highaltitude rocks and in Antarctic meteorites. Radiocarbon 31, 719-24.

Jull, A.J.T., Wilson, A.E., Burr, G.S., Toolin, L.J. and Donahue, D. 1992: Measurements of cosmogenic ${ }^{14} \mathrm{C}$ produced by spallation in high altitude rocks. Radiocarbon 34, 737-44.

Jull, A.J.T., Lal, D., Donahue, D.J., Mayewski, P., Lorius, C., Raynaud, D. and Petit, J.R. 1994a: Measurements of cosmic-ray-produced ${ }^{14} \mathrm{C}$ in firn and ice from Antarctica. Nuclear Instruments and Methods in Physics Research B 92, 326-30.

Jull, A.J.T., Lifton, N., Phillips, W.M. and Quade, J. 1994b: Studies of the production rate of cosmic ray produced ${ }^{14} \mathrm{C}$ in rock surfaces. Nuclear Instruments and Methods in Physics Research B 92, 308-10.

Kaplan, M.R., Miller, G.H. and Steig, E.J. 2001: Low-gradient outlet glaciers (ice streams?) drained the Laurentide ice sheet. Geology 29, 343-46.

Karhu, J.A., Tschudi, S., Saarnisto, M., Kubik, P. and Schlüchter, C. 2001: Constraints for the latest glacial advance on Wrangel Island, Arctic ocean from rock surface exposure dating. Global and Planetary Change 31, 447-51.

Kelly, M.A., von Blanckenburg, F., Kubik, P.W. and Schlüchter, C. 2002: Surface exposure ages of high elevation glacial erosion landforms: an attempt to date deglaciation of the Last Glacial Maximum ice cap in the western Swiss Alps. Geochimica et Cosmochimica Acta 66, S1, A392.

Kirchner, J., Finkel, R.C., Riebe, C., Granger, D.E., Clayton, J.L., King, J.G. and Megahan, W.F. 2001: Mountain erosion over 10 yr, 10 k.y., and 10 m.y. timescales. Geology 29, 591-94.

Klein, J., Middleton, R. and Tang, H-Q. 1982: Modifications of an FN Tandem for quantitative measurements of ${ }^{10} \mathrm{Be}$. Nuclear Instruments and Methods in Physics Research B 193, 601-16.

Klein, J., Giegengack, R., Middleton, R., Sharma, P., Underwood, J.R. and Weeks, R.A. 1986: Revealing histories of exposure using in situ produced ${ }^{26} \mathrm{Al}$ and ${ }^{10} \mathrm{Be}$ in Libyan Desert Glass. Radiocarbon 28, 547-55. 
Klinger, Y., Avouac, J.P., Abou Karaki, N., Dorbath, L., Bourlès, D. and Reyss, J.L. 2000: Slip rate on the Dead Sea transform fault in northern Araba valley (Jordan). Geophysical Journal International 142, 755-68.

Kober, F., Schlunegger, F., Ivy-Ochs, S. and Weiler, R. 2002: The dependency of cosmogenic nuclides to climate and surface uplift in transient landscapes. Geochimica et Cosmochimica Acta 66, S1, A408.

Kubik, P.W., Ivy-Ochs, S., Schlüchter, C., Masarik, J. and Frank, M. 1998: ${ }^{10} \mathrm{Be}$ and ${ }^{26} \mathrm{Al}$ production rates deduced from an instantaneous event within the dendro-calibration curve, the landslide of the Köfels Otz Valley Austria. Earth and Planetary Science Letters 161, 231-41.

Kurz, M.D. 1986a: Cosmogenic helium in a terrestrial igneous rock. Nature 320, 435-39.

1986b: In situ production of terrestrial cosmogenic helium and some applications to geochronology. Geochimica et Cosmochimica Acta 50, 2855-62.

- 1987: Erratum: in situ production of terrestrial cosmogenic helium and some applications to geochronology. Geochimica et Cosmochimica Acta 51, 1019.

Kurz, M.D. and Brook, E.J. 1994: Surface exposure dating with cosmogenic nuclides. In: Beck, C., editor, Dating in exposed and surface contexts. Albuquerque NM: University of New Mexico Press, 139-59.

Kurz, M.D., Colodner, D., Trull, T.W., Moore, R.B. and O'Brien, K. 1990: Cosmic ray exposure dating with in situ produced cosmogenic ${ }^{3} \mathrm{He}$ : results from young Hawaiian lava flows. Earth and Planetary Science Letters 97, 177-89.

Lal, D. 1988: In-situ-produced cosmogenic isotopes in terrestrial rocks. Annual Reviews in Earth and Planetary Science 16, 355-88.

-_- 1991: Cosmic ray labelling of erosion surfaces: in situ nuclides production rates and erosion models. Earth and Planetary Science Letters 104, 424-39.

Lal, D. and Arnold, J.R. 1985: Tracing quartz through the environment. Proceedings of the Indian Academy of Science, Earth and Planetary Science 94, 1-5.

Lal, D. and Jull, A.J.T. 1990: On determining ice accumulation rates in the past 40,000 years using in-situ cosmogenic C-14. Geophysical Research Letters 17, 1303-306.

- 1992: Cosmogenic nuclides in ice sheets. Radiocarbon 34, 227-33.
2001: In-situ cosmogenic C-14: production and examples of its unique applications in studies of terrestrial and extraterrestrial processes. Radiocarbon 43, 731-42.

Lal, D. and Peters, B. 1967: Cosmic ray produced radioactivity on the Earth. In Sitte, K., editor, Handbuch der Physik XLVI/2 (46/2). Springer Verlag, Berlin, 551-612.

Lal, D., Nishiizumi, K. and Arnold, J. 1987: Insitu-produced cosmogenic ${ }^{3} \mathrm{H},{ }^{14} \mathrm{C}$, and ${ }^{10} \mathrm{Be}$ for determining the net accumulation and ablation of ice sheets. Journal of Geophysical Research 92, 4947-52.

Lal, D., Jull, A.J.T. and Donahue, D.J. 1990: Polar ice ablation rates measured using in-situ cosmogenic C-14. Nature 346, 350-52.

Laughlin, A.W., Poths, J., Healy, H.A., Reneau, S. and WoldeGabriel, G. 1994: Dating of Quaternary basalts using the cosmogenic ${ }^{3} \mathrm{He}$ and ${ }^{14} \mathrm{C}$ methods with implications for excess ${ }^{40}$ Ar. Geology 22, 135-38.

Leland, J., Reid, M.R., Burbank, D.W., Finkel, R. and Caffee, M. 1998: Incision and differential bedrock uplift along the Indus River near Nanga Parbat, Pakistan Himalaya, from ${ }^{10} \mathrm{Be}$ and ${ }^{26} \mathrm{Al}$ exposure age dating of bedrock straths. Earth and Planetary Science Letters 154, 93-107.

Licciardi, J.M., Kurz, M.D., Clark, P.U. and Brook, E.J. 1999: Calibration of cosmogenic ${ }^{3} \mathrm{He}$ production rates from Holocene lava flows in Oregon, USA, and effects of the Earth's magnetic field. Earth and Planetary Science Letters 172, 261-71.

Licciardi, J.M., Clark, P.U., Brook, E.J., Pierce, K.L., Kurz, M.D., Elmore, D. and Sharma, P., 2001: Cosmogenic ${ }^{3} \mathrm{He}$ and ${ }^{10} \mathrm{Be}$ chronologies of the late Pinedale northern Yellowstone ice cap, Montana, USA. Geology 29, 1095-98.

Lifton, N.A., Jull, A.J.T. and Quade, J. 2001: A new extraction technique and production rate estimate for in situ cosmogenic ${ }^{14} \mathrm{C}$ in quartz. Geochimica et Cosmochimica Acta 65, 1953-69.

Lifton, N., Pigati, J., Jull, A.J.T. and Quade, J. 2002: Altitudinal variation of in situ cosmogenic ${ }^{14} \mathrm{C}$ production rates: preliminary results from the Southerwestern USA. Geochimica et Cosmochimica Acta 66, S1, A457.

Liu, B.L., Phillips, F.M., Elmore, D. and Sharma, P. 1994: Depth dependence of soil carbonate accumulation based on cosmogenic ${ }^{36} \mathrm{Cl}$ dating. Geology 22, 1071-74.

Liu, B.L., Phillips, F.M., Pohl, M.M. and Sharma, P. 1996: An alluvial surface chronology based on cosmogenic ${ }^{36} \mathrm{Cl}$ dating, Ajo Mountains (Organ Pip Cactus National Monument) 
southern Arizona. Quaternary Research 45, 30-37.

Loosli, H. 1983: A dating method with argon-39. Earth and Planetary Science Letters 63, 51-62.

Marchant, D.R., Lewis, A.R., Phillips, W.M., Moore, E.J., Souchez, R.A., Denton, G.H., Sugden, D.E., Potter, N. and Landis, G.P. 2002: Formation of patterned ground and sublimation till over Miocene glacier ice in Beacon Valley, southern Victoria Land Antarctica. Geological Society of America Bulletin 114, 718-30.

Marsella, K.A., Bierman, PR., Davis, P.T. and Caffee, M.W. 2000: Cosmogenic Be-10 and Al26 ages for the Last Glacial Maximum, eastern Baffin Island, Arctic Canada. Geological Society of America Bulletin 112, 1296-312.

Marti, K. and Craig, H. 1987: Cosmic-rayproduced neon and helium in the summit lavas of Maui. Nature 325, 335-37.

Masarik, J. 2002: Numerical simulation of in-situ production of cosmogenic nuclides. Geochimica et Cosmochimica Acta 66 S1, 491, 1

Masarik, J. and Reedy, R.C. 1995: Terrestrial cosmogenic-nuclides production systematics calculated from numerical simulations. Earth and Planetary Science Letters 136, 381-95.

Masarik, J., Frank, M., Schäfer, J.M. and Wieler, R. 2001: Correction of in situ cosmogenic nuclides production rates for geomagnetic field intensity variation during the past 800,000 years. Geochimica et Cosmochimica Acta 65, 2995-3003.

McKean, J.A., Dietrich, W.E., Finkel, R.C., Southon, J.R., Caffee, M.W. 1993: Quantification of soil production and downslope creep rates from cosmogenic ${ }^{10} \mathrm{Be}$ accumulations on a hillslope profile. Geology 21, 343-46.

Miller, G.H., Wolfe, A.P., Steig, E.J, Sauer, P.E., Kaplan, M.R. and Briner, J.P. 2002: The Goldilocks dilemma: big ice, little ice or 'just right' ice in the Eastern Canadian arctic. Quaternary Science Reviews 21, 33-48.

Mitchell, S.G., Matmon, A., Bierman, P.R., Enzel, Y., Caffee, M. and Rizzo, D. 2001: Displacement history of a limestone fault scarp, northern Israel, from cosmogenic ${ }^{36} \mathrm{Cl}$. Journal of Geophysical Research 106, 4247-64.

Molnar, P., Brown, E.T., Burchfiel, C., Qidpong, D., Xianyue, F., Jun, L., Raisbeck, G.M., Jianbang, S., Zhangming, W., Yiou, F. and Huichuan, Y. 1994: Quaternary climate change and the formation of river terraces across growing anticlines on the north flank of the Tien Shan, China. The Journal of Geology 102, 583-602.
Nichols, K.K., Bierman, P.R., Hooke, R.L., Clapp, E.M. and Caffee, M. 2002: Quantifying sediment transport on desert peidmonts using ${ }^{10} \mathrm{Be}$ and ${ }^{26} \mathrm{Al}$. Geomorphology 45, 105-25.

Niedermann, S., Graf, T., Kim, J.S., Kohl, C.P., Marti, K. and Nishiizumi, K. 1994: Cosmicray-produced ${ }^{21} \mathrm{Ne}$ in terrestrial quartz: the neon inventory of Sierra Nevada quartz separates. Earth and Planetary Science Letters 125, 341-55.

Nishiizumi, K., Lal, D., Klein, J., Middleton, R. and Arnold, J.R. 1986: Production of ${ }^{10} \mathrm{Be}$ and ${ }^{26} \mathrm{Al}$ by cosmic rays in terrestrial quartz in situ and implications for erosion rates. Nature 319, 134-36.

Nishiizumi, K., Winterer, E.L., Kohl, C.P., Klein, J., Middleton, R., Lal, D. and Arnold, J.R. 1989: Cosmic ray production rates of ${ }^{10} \mathrm{Be}$ and ${ }^{26} \mathrm{Al}$ in quartz from glacially polished rocks. Journal of Geophysical Research 94, 17 907-15.

Nishiizumi, K., Klein, J., Middleton, R. and Craig, H. 1990: Cosmogenic ${ }^{10} \mathrm{Be},{ }^{26} \mathrm{Al}$ and ${ }^{3} \mathrm{He}$ in olivine from Maui lavas. Earth and Planetary Science Letters 98, 263-66.

Nishiizumi, K., Kohl, C.P., Shoemaker, E.M., Arnold, J.R., Klein, J., Fink, D. and Middleton, R. 1991a: In-situ ${ }^{10} \mathrm{Be}$ and ${ }^{26} \mathrm{Al}$ exposure age at Meteor Crater, Arizona. Geochimica et Cosmochimica Acta 55, 2699-703.

Nishiizumi, K., Kohl, C.P., Arnold, J.R., Klein, J., Fink, D. and Middleton, R. 1991b: Cosmic ray produced ${ }^{10} \mathrm{Be}$ and ${ }^{26} \mathrm{Al}$ in Antarctic rocks: exposure and erosion history. Earth and Planetary Science Letters 104, 440-54.

Nishiizumi, K., Kohl, C.P., Arnold, J.R., Dorn, R., Klein, J., Fink, D., Middleton, R. and Lal, D. 1993: Role of in-situ cosmogenic nuclides ${ }^{10} \mathrm{Be}$ and ${ }^{26} \mathrm{Al}$ in the study of diverse geomorphic processes. Earth Surface Processes and Landforms 18, 407-25.

Nishiizumi, K., Finkel, R.C., Klein, J. and Kohl, C.P. 1996: Cosmogenic production of ${ }^{7} \mathrm{Be}$ and ${ }^{10} \mathrm{Be}$ in water targets. Journal of Geophysical Research 101, 22 225-32.

Noller, J.S., Sowers, J.M. and Lettis, W.R., editors 2000: Quaternary geochronology, methods and applications. Washington DC: American Geophysical Union, 582 pp.

Oberholzer, P., Schäfer, J.M., Baroni, C., IvyOchs, S., Orombelli, G., Baur, H. and Wieler, R. 2002: Limited Pleistocene glaciation in Deep Freeze Range, Northern Victoria Land, Antarctica, derived from in situ cosmogenic nuclides. Geochimica et Cosmochimica Acta 66, S1, A565.

Owen, L.A., Gualtieri, L., Finkel, R.C., Caffee, 
M.W., Benn, D.I. and Sharma, M.C. 2001: Cosmogenic radionuclide dating of glacial landforms in the Lahul Himalaya, northern India: defining the timing of Late Quaternary glaciation. Journal of Quaternary Science 16, 555-63.

Owen, L.A., Finkel, R.C. and Caffee, M.W. 2002a: A note on the extent of glaciation throughout the Himalya during the global Last Glacial Maximum. Quaternary Science Reviews 21, 89-101.

Owen, L.A., Finkel, R.C., Caffee, M.W. and Gualtieri, L. 2002b: Timing of multiple late Quaternary glaciations in the Hunza Valley, Karakoram Mountains, northern Pakistan: Defined by cosmogenic radionuclide dating of moraines. Geological Society of America Bulletin 114, 593-604.

-_ 2002c: Reply: cosmogenic radionuclides dating of glacial landforms in the Lahul Himalya, northern India: defining the timing of Late Quaternary glaciation. Journal of Quaternary Science 17, 279-81.

Perg, L.A., Anderson, R.S. and Finkel, R.C. 2001: Use of a new ${ }^{10} \mathrm{Be}$ and ${ }^{26} \mathrm{Al}$ inventory method to date marine terraces, Santa Cruz, California USA. Geology 29, 879-82.

Phillips, F.M. 2000: Muogenic nuclides: a method for dating rapidly eroding landforms. Geochimica et Cosmochimica Acta 66, S1, A599.

Phillips, F.M. and Bowen, D.Q. 2002: A comparison of cosmogenic chronologies for deglaciation in western North America and Europe. Geochimica et Cosmochimica Acta 66, S1, A598.

Phillips, F.M., Leavy, B.D., Jannick, N.O., Elmore, D. and Kubik, P.W. 1986: The accumulation of cosmogenic chlorine-36 in rocks: a method for surface exposure dating. Science 231, 41-43.

Phillips, F.M., Zreda, M.G., Smith, S.S., Elmore, D., Kubik, P.W. and Sharma, P. 1990: Cosmogenic chlorine-36 chronology for glacial deposits at Bloody Canyon, Eastern Sierra Nevada. Science 248, 1529-32.

Phillips, F.M., Zreda, M.G., Smith, S.S., Elmore, D., Kubik, P.W., Dorn, R.I. and Roddy, D.J. 1991: Age and geomorphic history of Meteor Crater, Arizona, from cosmogenic ${ }^{36} \mathrm{Cl}$ and ${ }^{14} \mathrm{C}$ in rock varnish. Geochimica et Cosmochimica Acta 55, 2695-98.

Phillips, F.M., Zreda, M.G., Benson, L.V., Plummer, M.A., Elmore, D. and Sharma, P. 1996: Chronology for fluctuations in Late Pleistocene Sierra Nevada glaciers and lakes.
Science 274, 749-51.

Phillips, F.M., Zreda, M.G., Evenson, E.B., Hall R.D., Chadwick, O.A., Sharma, P. 1997: Cosmogenic ${ }^{36} \mathrm{Cl}$ and ${ }^{10} \mathrm{Be}$ ages of Quaternary glacial and fluvial deposits of the Wind River Range Wyoming. Geological Society of America Bulletin 109, 1453-63.

Phillips, W.M. 2000: Estimating cumulative soil accumulation rates with in situ produced cosmogenic nuclide depth profiles. Nuclear Instruments and Methods in Physics Research B 172, 817-21.

-_- 2001: A review of cosmogenic nuclide surface exposure dating: new challenges for Scottish geomorphology. Scottish Geographical Journal 117, 1-15.

Phillips, W.M., McDonald, E.V., Reneau, S.L. and Poths, J. 1998: Dating soils and alluvium with cosmogenic ${ }^{21} \mathrm{Ne}$ depth profiles: case studies from the Pajarito Plateau, New Mexico, USA. Earth and Planetary Science Letters 160, 209-23.

Phillips, W.M., Sloan, V.F., Shroder, J.F., Sharma, P., Clarke, M. and Rendell, H.M. 2000: Asynchronous glaciation at Nanga Parbat, northwestern Himalaya Mountains, Pakistan. Geology 28, 431-34.

Poreda, R.J. and Cerling, T.E. 1992: Cosmogenic neon in recent lavas from the Western United States. Geophysical Research Letters 19, 1863-66.

Pratt, B., Burbank, D.W., Heimsath, A. and Ojha, T. 2002: Impulsive alluviation during early Holocene strengthened monsoons, central Nepal Himalaya. Geology 30, 911-14.

Repka, J.L., Anderson, R.S. and Finkel, R.C. 1997: Cosmogenic dating of fluvial terraces, Fremont River, Utah. Earth and Planetary Science Letters 152, 59-73.

Reynolds, R.W., Geist, D. and Kurz, M.D. 1995: Physical volcanology and structural development of Sierra Negra Volcano, IsabellaIsland, Galapagos Archipelago. Geological Society of America Bulletin 107, 1398-410.

Riebe, C.S., Kirchner, J.W., Granger, D.E. and Finkel, R.C. 2000: Erosional equilibrium and disequilibrium in the Sierra Nevada, inferred from cosmogenic ${ }^{26} \mathrm{Al}$ and ${ }^{10} \mathrm{Be}$ in alluvial sediment. Geology 28, 803-806.

Riebe, C.S., Kirchner, J.W. and Granger, D.E. 2001a: Quantifying quartz enrichment and its consequences for cosmogenic measurements of erosion rates from alluvial sediment and regolith. Geomorphology 40, 15-19.

Riebe, C.S., Kirchner, J.W., Granger, D.E. and Finkel, R.C. 2001b: Strong tectonic and weak 
climatic control of long-term chemical weathering. Geology 29, 511-14.

— 2001c: Minimal climatic control on erosion rates in the Sierra Nevada, California. Geology $29,447-50$.

Ritz, J.F., Brown, E.T., Bourlès, D.L., Philip, H., Schlupp, A., Raisbeck, G.M., Yiou, F. and Enkhtuvshin, B. 1995: Slip rates along active faults estimated with cosmic ray exposure dates: applications to the Bogd Faults, GobiAltai, Mongolia. Geology 23, 1019-22.

Sarda, P., Staudacher, T., Allègre, C.J. and Lecomts, A. 1993: Cosmogenic neon and helium at Réunion: measurement of erosion rate. Earth and Planetary Science Letters 119, 405-17.

Schäfer, J.M., Ivy-Ochs, S., Wieler, R., Leya, I., Baur, H., Denton, G.H. and Schlüchter, C. 1999: Cosmogenic noble gas studies in the oldest landscape on earth: surface exposure ages of the Dry Valleys, Antarctica. Earth and Planetary Science Letters 167, 215-26.

Schäfer, J.M., Baur, H., Denton, G.H., Ivy-Ochs, S., Marchant, D.R., Schlüchter, C. and Wieler, R. 2000: The oldest ice on Earth in Beacon Valley, Antarctica: new evidence from surface exposure dating. Earth and Planetary Science Letters 179, 91-99.

Schäfer, J.M., Tschudi, S., Zhao, Z.Z., Wu, X., Ivy-Ochs, S., Wieler, R., Baur, H., Kubik, P.W. and Schlüchter, C. 2002a: The limited influence of glaciations in Tibet on global climate over the past 170,000 yr. Earth and Planetary Science Letters 194, 287-97.

Schäfer, J.M., Ivy-Ochs, S., Denton, G.H., Schlüchter, C., Weiler, R., Kubik, P.W. and Schlosser, P. 2002b: Rise and fall of the Last Glacial Maximum. Geochimica et Cosmochimica Acta 66, S1, 672.

Schaller, M., von Blanckenburg, F., Hovius, N. and Kubik, P.W. 2001: Large-scale erosion rates from in situ-produced cosmogenic nuclides in European river sediments. Earth and Planetary Science Letters 188, 441-58.

2002 Palaeo-erosion rate record in a $1.6 \mathrm{Ma}$ terrace sequence of the Meuse river. Geochimica et Cosmochimica Acta 66, S1, 673.

Schildgen, T., Dethier, D.P., Bierman, P. and Caffee, M. 2002: ${ }^{26} \mathrm{Al}$ and ${ }^{10} \mathrm{Be}$ dating of late Pleistocene and Holocene fill terraces: a record of fluvial deposition and incision, Colorado front range. Earth Surface Processes and Landforms 27, 773-87.

Schroeder, P.A., Melear, N.D., Bierman, P., Kashgarian, M. and Caffee, M. 2001: Apparent gibbsite growth ages for regolith in the Georgia
Piedmont. Geochimica et Cosmochimica Acta 65, 381-86,

Seidl, M.A., Finkel, R.C., Caffee, M.W., Hudson, G.B. and Dietrich, W.E. 1997: Cosmogenic isotope analyses applied to river longitudinal profile evolution: problems and interpretations. Earth Surface Processes and Landforms 22, 195-210.

Shanahan, T.M. and Zreda, M. 2000: Chronology of Quaternary glaciations in East Africa. Earth and Planetary Science Letters 177, 23-42.

Shepard, M.K., Arvidson, R.E., Caffee, M., Finkel, R. and Harris, L. 1995: Cosmogenic exposure ages of basalt flows: Lunar Crater volcanic field, Nevada. Geology 23, 21-4.

Siame, L.L., Bourlès, D.L., Sébrier, M., Bellier, O., Castano, J.C., Araujo, M., Perez, M., Raisbeck, G.M. and Yiou, F. 1997: Cosmogenic dating ranging from 20 to $700 \mathrm{ka}$ of a series of alluvial fan surfaces affected by the El Tigre fault, Argentina. Geology 25, 975-78.

Siame, L.L., Bellier, O., Sébrier, M., Bourlès, D.L., Leturmy, P., Perez, M. and Araujo, M. 2002: Seismic hazard reappraisal from combined structural geology, geomorphology and cosmic-ray exposure dating analyses: the Eastern Precordillera thrust system (NW Argentina). Geophysical Journal International 150, 241-60.

Small, E.E., Anderson, R.S., Repka, J.L. and Finkel, R. 1997: Erosion rates of alpine bedrock summit surfaces deduced from in situ ${ }^{10} \mathrm{Be}$ and ${ }^{26} \mathrm{Al}$. Earth and Planetary Science Letters 150, 413-25.

Small, E.E., Anderson, R.S. and Hancock, G.S. 1999: Estimates of the rates of regolith production using ${ }^{10} \mathrm{Be}$ and ${ }^{26} \mathrm{Al}$ from an alpine hillslope. Geomorphology 27, 131-50.

Srinivasan, B. 1976: Barites: anomalous xenon from spallation and neutron-induced reactions. Earth and Planetary Science Letters 106, 87-102.

Stanford, S.D., Seidl, M.A. and Ashley, G.M. 2000: Exposure ages and erosional history of an upland planation surface in the US Atlantic Peidmont. Earth Surface Processes and Landforms 25, 939-50.

Staudacher, T. and Allègre, C.J. 1993: Ages of the second caldera of Piton de la Fournaise volcano (Réunion) determined by cosmic ray produced ${ }^{3} \mathrm{He}$ and ${ }^{21} \mathrm{Ne}$. Earth and Planetary Science Letters 119, 395-404.

Steig, E.J., Wolfe, A.P. and Miller, G.H. 1998: Wisconsinan refugia and the glacial history of eastern Baffin Island Arctic Canada: couple evidence from cosmogenic isotopes and lake sediments. Geology 26, 835-38.

Stone, J.O. 2000: Air pressure and cosmogenic 
isotope production. Journal of Geophysical Research 105, 23753-59.

- 2002: Calibration and scaling of cosmogenic nuclides production rates. Geochimica et Cosmochimica Acta 66, S1, 746.

Stone, J., Allan, G.L., Fifield, L.K., Evans, J.M. and Chivas, A.R. 1994: Limestone erosion measurements with cosmogenic ${ }^{36} \mathrm{Cl}$ in calcite preliminary results from Australian. Nuclear Instruments and Methods in Physics Research B 92, 311-16.

Stone, J., Lambeck, K., Fifield, L.K., Evans, J.M. and Cresswell, R.G. 1996: A Lateglacial age for the Main Rock Platform, Western Scotland. Geology 24, 707-10.

Stone, J.O.H., Evans, J.M., Fifield, L.K., Allan, G.L. and Cresswell, R.G. 1998a: Cosmogenic chlorine-36 production in calcite by muons. Geochimica et Cosmochimica Acta 62, 433-54.

Stone, J.O., Ballantyne, C.K. and Fifield, L.K. 1998b: Exposure dating and validation of periglacial weathering limits, northwest Scotland. Geology 26, 587-90.

Stone, J.O., Balco, G., Sugden, D.E., Caffee, M.W., Siddoway, C., Cowdery, S. and Sass, L. 2002: $10^{3}-10^{6}$ year history of the West Antarctic ice sheet. Geochimica et Cosmochimica Acta 66, $\mathrm{S} 1,745$.

Stroeven, A.P., Fabel, D., Hattestrand, C. and Harbor, J. 2002: A relict landscape in the centre of the Fennoscandian glaciation: cosmogenic radionuclide evidence of tors preserved through multiple glacial cycles. Geomorphology $44,145-154$.

Sugden, D.E., Marchant, D.R., Potter, N., Jr, Souchex, R., Denton, G.H., Swisher, C.C. and Tison, J-L. 1995: Miocene glacier ice in Beacon Valley, Antarctica. Nature 376, 412-16.

Summerfield, M.A., Stuart, F.M., Cockburn, H.A.P., Sugden, D.E., Denton, G.H., Dunai, T. and Marchant, D.R. 1999a: Long-term rates of denudation in the Dry Valleys, Transantarctic Mountains, southern Victoria Land, Antarctica based on in-situ produced cosmogenic ${ }^{21} \mathrm{Ne}$. Geomorphology 27, 113-29.

Summerfield, M.A., Sugden, D.E., Denton, G.H., Marchant, D.R., Cockburn, H.A.P. and Stuart, F.M. 1999b: Cosmogenic data support previous evidence of extremely low rates of denudation in the Dry valleys region, southern Victoria Land, Antarctica. In Smith, B.J., Whalley, W.B. and Warke, P.A., editors, Uplift erosion and stability: perspectives on longterm landscape development. London: Geological Society of London Special Publications 162, 255-67.
Taylor, P.J. and Mitchell, W.A. 2002: Comment: cosmogenic radionuclides dating of glacial landforms in the Lahul Himalaya, northern India: defining the timing of Late Quaternary glaciation. Journal of Quaternary Science 17, 277-78.

Trull, T.W., Kurz, M.D. and Jenkins, W.J. 1991: Diffusion of cosmogenic ${ }^{3} \mathrm{He}$ in olivine and quartz - implications for surface exposure dating. Earth and Planetary Science Letters 103, 241-56.

Trull, T.W., Brown, E.T., Marty, B., Raisbeck, G.M. and Yiou, F. 1995: Cosmogenic ${ }^{10} \mathrm{Be}$ and ${ }^{3} \mathrm{He}$ accumulation in Pleistocene beach terraces in Death Valley, California, USA. Implications for cosmic-ray exposure dating of young surfaces in hot climates. Chemical Geology 119, 191-207.

Tschudi, S., Ivy-Ochs, S., Schlüchter, C., Kubik, P. and Rainio, H. 2000: Be-10 dating of Younger Dryas Salpausselka I formation in Finland. Boreas 29, 287-93.

Tuniz, C., Bird, J.R., Fink, D. and Herzog, G.F. 1998: Accelerator mass spectrometry, ultrasensitve analysis for global science. Boca Raton FL: CRC Press, 371 pp.

Van der Wateren, F.M. and Dunai, T.J. 2001: Late Neogene margin denudation history cosmogenic measurements from the central Namib Desert. Global and Planetary Change 30, 271-307.

Van der Wateren, F.M., Dunai, T.J., Van Balen, R.T., Klas, W., Verbers, A.L.L.M., Passchier, S. and Herpers, U. 1999: Contrasting Neogene denudation histories of different structural regions in the Transantarctic Mountains rift flank constrained by cosmogenic isotope measurements. Global and Planetary Change 23, 145-72.

Van der Woerd, J., Ryerson, F.J., Tapponier, P., Gaudemer, Y., Finkel, R., Meriaux, A.S., Caffee, M., Guoguang, Z. and Qunlu, H. 1998: Holocene left-slip rate determined by cosmogenic surface dating on the Xidatan segment of the Kunlun fault (Qinghai, China). Geology 26, 695-98.

Van der Woerd, J., Tapponier, P., Ryerson, F.J., Meriaux, A-S., Mayer, B., Gaudemer, Y., Finkel, R.C., Caffee, M.W., Guoguang, Z. and Zhiqin, X. 2002: Uniform postglacial slip-rate along the central $600 \mathrm{~km}$ of the Kunlun Fault (Tibet), from ${ }^{26} \mathrm{Al},{ }^{10} \mathrm{Be}$ and ${ }^{14} \mathrm{C}$ dating of riser offsets, and climatic origin of the regional morphology. Geophysical Journal International $148,356-88$. 
Weissel, J.K. and Seidl, M.A. 1998: Inland propagation of erosional escarpments and river profile evolution across southeast Australian passive continental margin. In Tinkler, K.J. and Wohl, E.E., editors, Rivers over rock: fluvial processes in bedrock channels. AGU Geophysical Monograph Series 107, Washington DC: American Geophysical Union, 189-206.

Wells, S.G., McFadden, L.D., Poths, J. and Olinger, C.T. 1995: Cosmogenic ${ }^{3} \mathrm{He}$ surface exposure dating of stone pavements: implications for landscape evolution in deserts. Geology 23, 613-16.

Zehfuss, P.H., Bierman, P.R., Gillespie, A.R., Burke, R.M. and Caffee, M.W. 2001: Slip rates on the Fish Springs fault, Owens Valley, California, deduced from cosmogenic ${ }^{10} \mathrm{Be}$ and ${ }^{26} \mathrm{Al}$ and soil development on fan surfaces. Geological Society of America Bulletin 113, 241-55.

Zimmerman, S.G., Eveson, E.B., Gosse, J.C. and Erskine, C.P. 1994: Extensive boulder erosion resulting from a range fire on the Type-Pinedale Moraines, Fremont Lake, Wyoming. Quaternary Research 42, 255-65.

Zreda, M. and Noller, J.S. 1998: Ages of prehistoric earthquakes revealed by cosmogenic chlorine-36 in a bedrock fault scarp at Hebgen Lake. Science 282, 1097-99.

Zreda, M. and Phillips, F.M. 1995: Insights into alpine moraine development from cosmogenic ${ }^{36} \mathrm{Cl}$ build up dating. Geomorphology 14, 149-56. 2000: Cosmogenic nuclides build-up in surficial materials. In Noller, J.S., Sowers, J.M. and Lettis, W.R., editors, Quaternary geochronology: methods and applications. AGU Reference Shelf Series, Washington DC: American Geophysical Union, 61-76.

Zreda, M., Phillips, F.M., Kubik, P.W., Sharma, P. and Elmore, D. 1993: Cosmogenic ${ }^{36} \mathrm{Cl}$ dating of a young basaltic eruption complex, Lathrop Wells, Nevada. Geology 21, 57-60.

Zreda, M.G., Phillips, F.M. and Elmore, D. 1994: Cosmogenic ${ }^{36} \mathrm{Cl}$ accumulation in unstable landforms 2. Simulations and measurement on eroding moraines. Water Resources Research 30, 3127-36.

Zreda, M., England, J., Phillips, F., Elmore, D. and Sharma, P. 1999: Unblocking of the Nares Strait by Greenland and Ellesmere ice sheet retreat 10,000 years ago. Nature 398, 139-42. 